Article

\title{
Analysis of Small and Medium-Scale River Flood Risk in Case of Exceeding Control Standard Floods Using Hydraulic Model
}

\author{
Zixiong Wang ${ }^{1,2,3,+}{ }^{+}$, Ya Sun ${ }^{4,+}$, Chunhui $\mathrm{Li}^{2}$, Ling Jin ${ }^{5}$, Xinguo Sun ${ }^{6}$, Xiaoli Liu ${ }^{1, *}$ and Tianxiang Wang ${ }^{2,6, *}$ \\ 1 School of Engineering, Anhui Agricultural University, Hefei 230036, China; zxwang0817@163.com \\ 2 School of Ocean Science and Technology, Dalian University of Technology, Panjin 124221, China; \\ lichunhui123123@mail.dlut.edu.cn \\ 3 Guangzhou Pearl River Water Resources Protection Technology Development Co. Ltd., Pearl River Water \\ Resources Commission of the Ministry of Water Resources, Guangzhou 510635, China \\ 4 College of Environmental Sciences and Engineering, Dalian Maritime University, Dalian 116026, China; \\ 13322246994@163.com \\ 5 Hydrology and Water Resources Survey Bureau of Zhumadian, Zhumadian 463000, China; \\ evan_cools@163.com \\ 6 Jiangsu Smart Factory Engineering Research Center, Huaiyin Institute of Technology, Huaian 223003, China; \\ sunxinguo48144562@163.com \\ * Correspondence: xl.liu@ahau.edu.cn (X.L.); tianxiang@dlut.edu.cn (T.W.) \\ + These authors contributed equally to this work.
}

check for updates

Citation: Wang, Z.; Sun, Y.; Li, C.; Jin, L.; Sun, X.; Liu, X.; Wang, T. Analysis of Small and Medium-Scale River Flood Risk in Case of Exceeding Control Standard Floods Using Hydraulic Model. Water 2022, 14, 57. https://doi.org/10.3390/w14010057

Academic Editor: Michalis Diakakis

Received: 20 November 2021

Accepted: 22 December 2021

Published: 28 December 2021

Publisher's Note: MDPI stays neutral with regard to jurisdictional claims in published maps and institutional affiliations.

Copyright: (C) 2021 by the authors. Licensee MDPI, Basel, Switzerland. This article is an open access article distributed under the terms and conditions of the Creative Commons Attribution (CC BY) license (https:// creativecommons.org/licenses/by/ $4.0 /)$.

\begin{abstract}
Exceeding control standard floods pose threats to the management of small and mediumscale rivers. Taking Fuzhouhe river as an example, this paper analyzes the submerged depth, submerged area and arrival time of river flood risk in the case of exceeding control standard floods (with return period of 20, 50, 100 and 200 years) through a coupled one- and two-dimensional hydrodynamic model, draws the flood risk maps and proposes emergency plans. The simulation results of the one-dimensional model reveal that the dikes would be at risk of overflowing for different frequencies of floods, with a higher level of risk on the left bank. The results of the coupled model demonstrate that under all scenarios, the inundation area gradually increases with time until the flood peak subsides, and the larger the flood peak, the faster the inundation area increases. The maximum submerged areas are $42.73 \mathrm{~km}^{2}, 65.95 \mathrm{~km}^{2}, 74.86 \mathrm{~km}^{2}$ and $82.71 \mathrm{~km}^{2}$ for four frequencies of flood, respectively. The change of submerged depth under different frequency floods shows a downward-upward-downward trend and the average submerged depth of each frequency floods is about $1.4 \mathrm{~m}$. The flood risk maps of different flood frequencies are created by GIS to analyze flood arrival time, submerged area and submerged depth to plan escape routes and resettlement units. The migration distances are limited within $4 \mathrm{~km}$, the average migration distance is about $2 \mathrm{~km}$, the vehicle evacuation time is less than $20 \mathrm{~min}$, and the walking evacuation time is set to about $70 \mathrm{~min}$. It is concluded that the flood risk of small and medium-scale rivers is a dynamic change process, and dynamic flood assessment, flood warning and embankment modification scheme should be further explored.
\end{abstract}

Keywords: small and medium-scale river; flood risk; submerged area; submerged depth; evacuation plan

\section{Introduction}

Flood poses a serious threat to social security and economic development [1,2]. The riparian zone is generally densely populated and highly economically developed, while it is particularly susceptible to flooding [3,4]. To reduce the probability of flood disaster, structural measures such as dams and levees are extensively employed [5,6]. Flood control works protect downstream region from being vulnerable to flooding, contributing to the concentration of populations and assets in these areas. However, this would bring even greater loss in the event of dam failure caused by exceeding control standard floods [7-9]. 
Against that background, flood risk management measures are widely explored as a beneficial complement to engineering measures [10,11]. Flood risk management analyzes flood processes and risk factors, and accordingly develops management plans to minimize flood hazards [12-14]. More specifically, flood risk mapping is explored to make contingency plans for flooding [15-17]. Floodplain management is implemented to achieve protection of the natural resources, function of floodplains, and reduced flood losses [18,19]. Low impact development provides technical design guidelines for development projects, to ensure that the modified hydrological cycle is close to its natural conditions [20-22]. Flood processes are analyzed to identify the weaknesses of flood control works to optimize their design and operation [23,24].

Flood control standards for rivers are developed according to the population size, area of farmland, socio-economic conditions, losses and impacts of floods, etc. in the area of protection [25]. For large-scale rivers, Flood control standards are generally much higher, and are well-equipped with flood control works such as dams, flood diversion projects and reservoirs $[25,26]$. In contrast, many small and medium-sized rivers are associated with relatively poor standards and are prone to flood hazards. [27,28]. Due to financial constraints, it is difficult in the short term to improve flood protection level of small and medium-sized rivers through the construction of additional flood control works [29]. Therefore, analyzing the process and risk of exceeding standard floods in small and medium-sized rivers and formulation of contingency plan is a better choice to reduce flood losses [30,31]. Flood risk is immediately caused by river breaches and spreading excessive water over the watershed [32,33]. The floodwater evolves in the river and once the water level exceeds the embankment in flood events, a breach is created and inundation occurs. [34,35]. Watershed-related information such as historical floods, river topography and socio-economic aspects is collected and analyzed to extract important industrial, residential, agricultural and commercial areas. [36,37]. Taking both natural environment and human activities into account, this method is simple and effective for preliminary analysis of flood risk. However, it is invalid for the prediction of dynamic flood process based on historical data. Another approach is the use of a hydrodynamic model, which is developed based on the water balance equation and the storage-discharge equation $[38,39]$. The model is suitable to quantify flood process and dynamically analyze flood risk process [40]. The Muskingum model and its improved models, as well as corresponding parameter optimization methods have been extensively studied and are applied to examine river flood evolution [41-43]. Environmental Fluid Dynamics Code (EFDC) and Mike combine the hydrodynamic and water quality module to simulate twodimensional mass transport processes, which are considered powerful tools to analyze flood process and environmental impacts [44-46]. River flood evolution can be described by a one-dimensional hydrodynamic model, and flood evolution in the floodplain can be simulated by a two-dimensional hydrodynamic model. After obtaining the flood process by simulation, the flood arrival time, submerged area, submerged depth, people, road network, socio-economic and other key elements are imported into GIS to describe the flood risk and generate the contingency plan $[47,48]$.

The extreme values during flood processes such as flood flow, depression, and hydraulic gradient have been well-examined to depict flood risk. However, flood risk is a dynamic process and changes constantly throughout the process, which affects the development of emergency plan. The objectives of this paper are to analyze the dynamic characteristics of flood arrival time, submerged area, submerged depth in case of exceeding control standard flood and to present evacuation plans.

\section{Materials and Methods}

\subsection{Study Area}

Fuzhou river $\left(121^{\circ} 34^{\prime} \sim 122^{\circ} 21^{\prime} \mathrm{E} ; 39^{\circ} 30^{\prime} \sim 39^{\circ} 59^{\prime} \mathrm{N}\right)$ originates from the south of Laomao Mountain in Dalian, Liaoning Province. It is the second largest river in Dalian, with a total length of $137 \mathrm{~km}$. The drainage area is $1628 \mathrm{~km}^{2}$, of which $724 \mathrm{~km}^{2}$ is in moun- 
tainous area, $681 \mathrm{~km}^{2}$ in hilly area and $223 \mathrm{~km}^{2}$ in plain area. The Fuzhouhe river basin is in warm temperate continental monsoon climate zone with an average temperature of $9.3{ }^{\circ} \mathrm{C}$ and an average annual precipitation of $550-700 \mathrm{~mm}$. The precipitation is mainly concentrated in flood seasons (June-September) which accounts for $75 \%$ of the annual precipitation. The current flood control standard is 10 -year return period (10\%). Liaoning suffered severe rainfall during the No. 10 Typhoon "Davi" from 3 August to 4 August 2012. Large areas within the province experienced varying degrees of flood disasters, such as collapsed houses, flooded farmland and damaged roads. Dalian suffered the most serious flood disaster of the last 20 years, and nearly 20,000 people were affected. The Dongfeng reservoir, which is located in the middle reach of Fuzhouhe river and is one of the most important flood control projects in the watershed, appeared to exceed the flood limit level. This paper took the downstream of Fuzhouhe river as an example to analyze the risk process under exceeding control standard floods and to provide the evacuation plans (Figure 1). The total length of the section studied in this paper is $46.3 \mathrm{~km}$ and the main tributaries in this reach are the Jiudao river, Taiyang river, Dasichuan river, Kaoshantunxi river, Zhenzhu river and Langu river. The remote sensing image (Figure 2) showed there are 11 main land-use types in this river section including water, agricultural land 1 (with vegetation), agricultural land 2 (without vegetation), woodland (dense), building land, woodland (sparse), dry sandy land/dry land, green vegetation, road, wet sandy land/wet land, and dam/gate. Agricultural land is the dominant land use type, and the main crops are corn, wheat and rice.

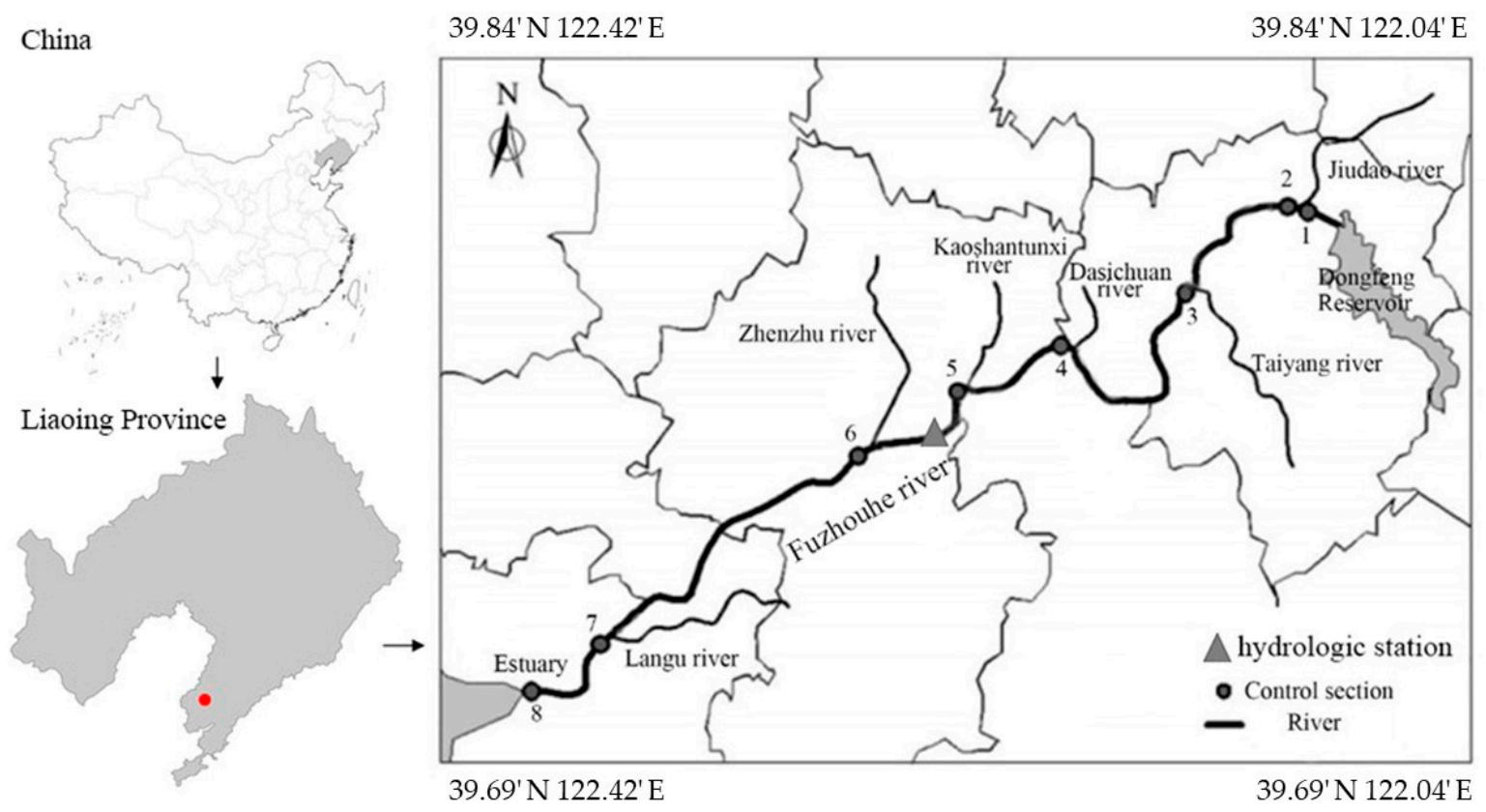

Figure 1. Schematic diagram of study area.

\subsection{Characteristics of Control Sections under Exceeding Control Standard Floods}

This paper analyzes the flood process under four frequencies of 20-year, 50-year, 100-year and 200-year, and the control standard for Fuzhouhe river is 10-year. The flood consists of interval flood and discharge from reservoirs. Muskingum model is used to calculate the peak discharge and flood hydrograph in each control section $[39,40]$. The interval flood process is provided by the Guanjiatun hydrological station, and the reservoir discharge is provided by Dongfeng Reservoir Administration. This paper used the Guanjiatun Hydrological Station to verify the rationality. The result validated with the hydrological data provided by Hydrologic frequency analysis method using Guanjiatun Hydrological Station data and the errors are between $-1.65 \sim 5.32 \%$ (Table 1). 


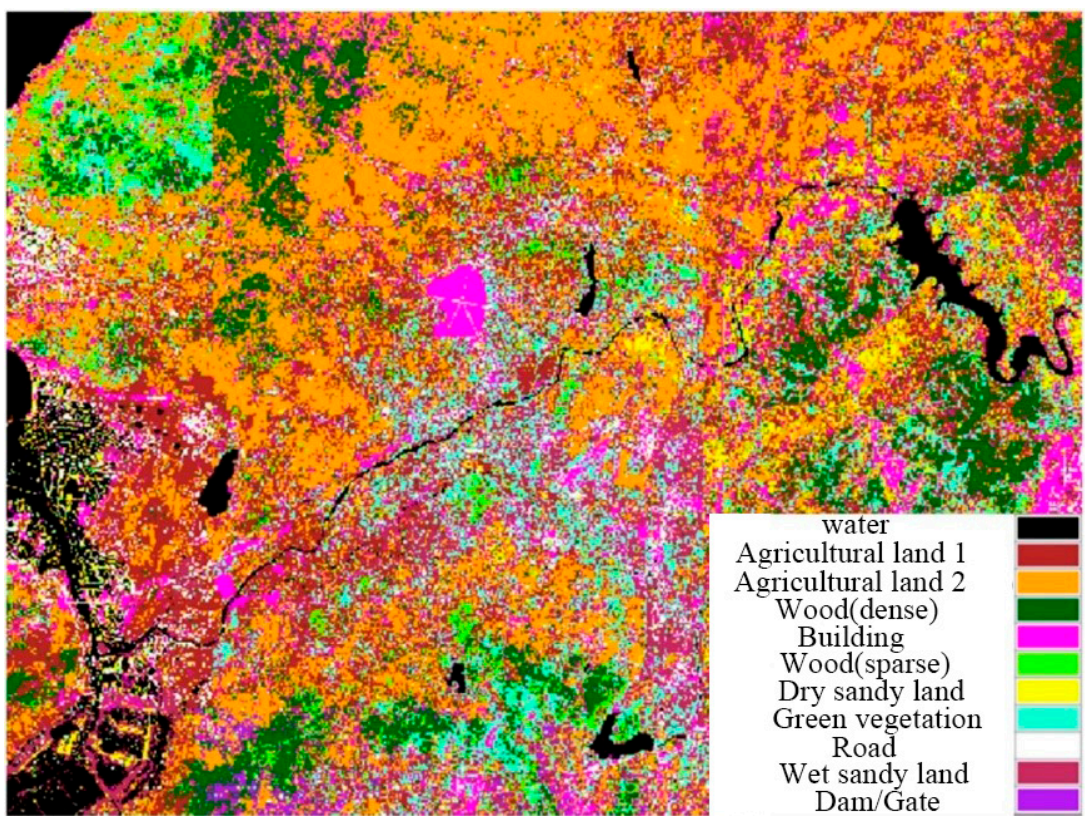

Figure 2. Remote sensing image of the study area.

Table 1. Result validation of Guanjiatun Hydrological Station $\mathrm{m}^{3} / \mathrm{s}$.

\begin{tabular}{ccccc}
\hline \multirow{2}{*}{ Method } & \multicolumn{4}{c}{ Flood Frequency } \\
\cline { 2 - 5 } & 20-Year (5\%) & 50-Year (2\%) & 100-Year (1\%) & 200-Year (0.5\%) \\
\hline Muskingum model & 1050 & 1757 & 2015 & 2140 \\
$\begin{array}{c}\text { Hydrologic frequency } \\
\text { analysis method }\end{array}$ & 2482 & 3370 & 3920 & 4277 \\
\hline
\end{tabular}

The calculation results are shown in Table 2 . The peak discharges of $0.5 \%, 1 \%, 2 \%$, and $5 \%$ frequencies of Dongfeng reservoir are $2140 \mathrm{~m}^{3} / \mathrm{s}, 2015 \mathrm{~m}^{3} / \mathrm{s}, 1757 \mathrm{~m}^{3} / \mathrm{s}$, and 1050 $\mathrm{m}^{3} / \mathrm{s}$, respectively, and the corresponding peak discharges at the estuary are $4277 \mathrm{~m}^{3} / \mathrm{s}$, $3920 \mathrm{~m}^{3} / \mathrm{s}, 3370 \mathrm{~m}^{3} / \mathrm{s}$, and $2482 \mathrm{~m}^{3} / \mathrm{s}$.

Table 2. Calculation results of peak discharge in each control section $\mathrm{m}^{3} / \mathrm{s}$.

\begin{tabular}{|c|c|c|c|c|c|}
\hline \multirow[b]{2}{*}{ No. } & \multirow[b]{2}{*}{ Control Section } & \multicolumn{4}{|c|}{ Flood Frequency } \\
\hline & & $\begin{array}{c}\text { 20-Year } \\
(5 \%)\end{array}$ & $\begin{array}{l}50-\text { Year } \\
(2 \%)\end{array}$ & $\begin{array}{c}\text { 100-Year } \\
(1 \%)\end{array}$ & $\begin{array}{c}\text { 200-Year } \\
(0.5 \%)\end{array}$ \\
\hline 1 & $\begin{array}{l}\text { Dongfeng Reservoir } \\
\text { section }\end{array}$ & 1050 & 1757 & 2015 & 2140 \\
\hline 2 & Jiudao River & 1369 & 2003 & 2319 & 2544 \\
\hline 3 & Taiyang River & 1445 & 2085 & 2513 & 2765 \\
\hline 4 & Dasichuan River & 1474 & 2130 & 2611 & 2851 \\
\hline 5 & Kaoshantunxi River & 1519 & 2180 & 2604 & 2924 \\
\hline 6 & Zhenzhu River & 1739 & 2248 & 2617 & 3023 \\
\hline 7 & Langu River & 2475 & 3360 & 3882 & 4227 \\
\hline 8 & Estuary & 2482 & 3370 & 3920 & 4277 \\
\hline
\end{tabular}

\subsection{One-Dimensional Hydrodynamic Model and Simulation of River Flood Process}

The process of river flood consists of two parts: the migration of flood water in the river, and the spreading of flood water from the breach to the floodplain. Considering that river channel is narrow, MIKE11 perfectly suitable for modeling the river flood process. The calculation principle of MIKE11 is unsteady flow in open channel (St. Venn's equations), 
which consists of a continuous equation and a motion equation [49]. The equation can be solved using the Abbott-Ionescu implicit scheme (6-points).

$$
\begin{gathered}
\frac{\partial Q}{\partial x}=\frac{\partial A}{\partial t} \\
\frac{\partial Q}{\partial t}+\frac{\partial\left(a \frac{Q^{2}}{A}\right)}{\partial x}+g A \frac{\partial h}{\partial x}+\frac{g Q|Q|}{C^{2} A R}=0
\end{gathered}
$$

where $Q$ is flow rate, $\mathrm{m}^{3} / \mathrm{s} ; A$ is cross-sectional area, $\mathrm{m}^{2} ; x, t$ are the distance and time, respectively; $h$ is water depth, $\mathrm{m} ; C$ is Chezy coefficient, $\mathrm{m}^{0.5} / \mathrm{s}$; $R$ is hydraulic radius, $\mathrm{m} ; g$ is gravitational acceleration, $\mathrm{m} / \mathrm{s}^{2}$; and $\alpha$ is correction coefficient.

The steps of modeling are as follows: (1) Generally, topography is a fundamental input to hydrologic models and is critical for river network extraction and analysis of floodwater movement. Preparation of the terrain data (1:1000) for the establishment of the model. The data is provided by Wafangdian Water Resources Survey and Design Co. Ltd. (2) Generalization of the river network. The principle is that the generalized river network should be generally consistent with the actual river network in terms of water conveyance capacity and storage capacity. Considering that the floods in the studied river section are mainly from the main stream, the inflow from tributaries is considered as an internal confluence point source. (3) Definition of boundary conditions. The inlet boundary is defined as the discharge flow from Dongfeng reservoir in the upstream with 20-, 50-, 100- and 200-year frequency floods. The data are provided by Dongfeng reservoir administration. The tributaries are treated as a point source, and the flow data is provided by the Fuzhouhe river administration. The outlet boundary takes the multi-year average tide level of $1.788 \mathrm{~m}$ which is sourced from Dalian Central Marine Station. The information of the river channel is obtained from Wafangdian River Channel Division. (4) Parameter setting. The riverbed is relatively flat and mainly composed of gravel and cobble, so the roughness is set to be $0.025-0.035$. The river beach is also flat, dominated by soil and sand interspersed with weeds and crops, and the roughness is taken to be in the range of $0.050-0.100$. The velocity distribution coefficient is 1.00 ; the water surface slope (Eps) is 0.0001 ; the minimum head loss coefficient is 0.10 , which are set as recommended by model manual. (5) Running the model. The model simulates the river flood process of different flood frequencies, and analyze the river water level to identify potential flood risks.

\subsection{Two-Dimensional Hydrodynamic Model and Simulation of Flood Risk in Floodplain}

After calculating the river flood evolution process with MIKE 11, the MIKE 11 and MIKE 21 are combined into MIKE FLOOD framework to further analyze the flooding process in the floodplain. The calculation principle is two-dimensional unsteady flow equations, including water continuity equation, the momentum equation of the water along $\mathrm{x}$-and $\mathrm{y}$-direction $[50,51]$.

$$
\left\{\begin{array}{c}
\frac{\partial z}{\partial t}+\frac{\partial(u h)}{\partial x}+\frac{\partial(v h)}{\partial y}=0 \\
\frac{\partial u}{\partial t}+u \frac{\partial u}{\partial x}+v \frac{\partial u}{\partial y}+g \frac{\partial z}{\partial x}+g \frac{n^{2} u \sqrt{u^{2}+v^{2}}}{h^{\frac{4}{3}}}=0 \\
\frac{\partial v}{\partial t}+u \frac{\partial v}{\partial x}+v \frac{\partial v}{\partial y}+g \frac{\partial z}{\partial y}+g \frac{n^{2} v \sqrt{u^{2}+v^{2}}}{h^{4}}=0
\end{array}\right.
$$

where $t$ is time; $n$ is manning coefficient; $x$ and $y$ are horizontal and vertical coordinates in rectangular coordinate system; $u$ and $v$ are velocity components in $x$ and $y$ direction; $z$ and $h$ are water level and depth at point $(x, y)$.

With Equation (3), the water level $z$, the water depth $h$, and velocity $u, v$ in the $x, y$ direction of the point $(x, y)$ at each time can be obtained through the iterative method.

The process of floodplain flood process modeling is as follows: (1) Creation of basic terrain documents with elevation points. (2) Adding embankments and water-blocking structures. (3) Determination of Manning coefficient according to land use from remote 
sensing data (Figure 3). (4) Determination of the boundary conditions. The flood routing of the river flood obtained by Mike 11 is used as the inflow conditions. Similarly, the average annual tide level of $1.788 \mathrm{~m}$ at the estuary is set as the outflow condition. (5) The Mike 11 and Mike 21 model are imported into the Mike FLOOD model to generate the coupling model to simulate the flood processes and analyze the changes of the submerged depth and area.

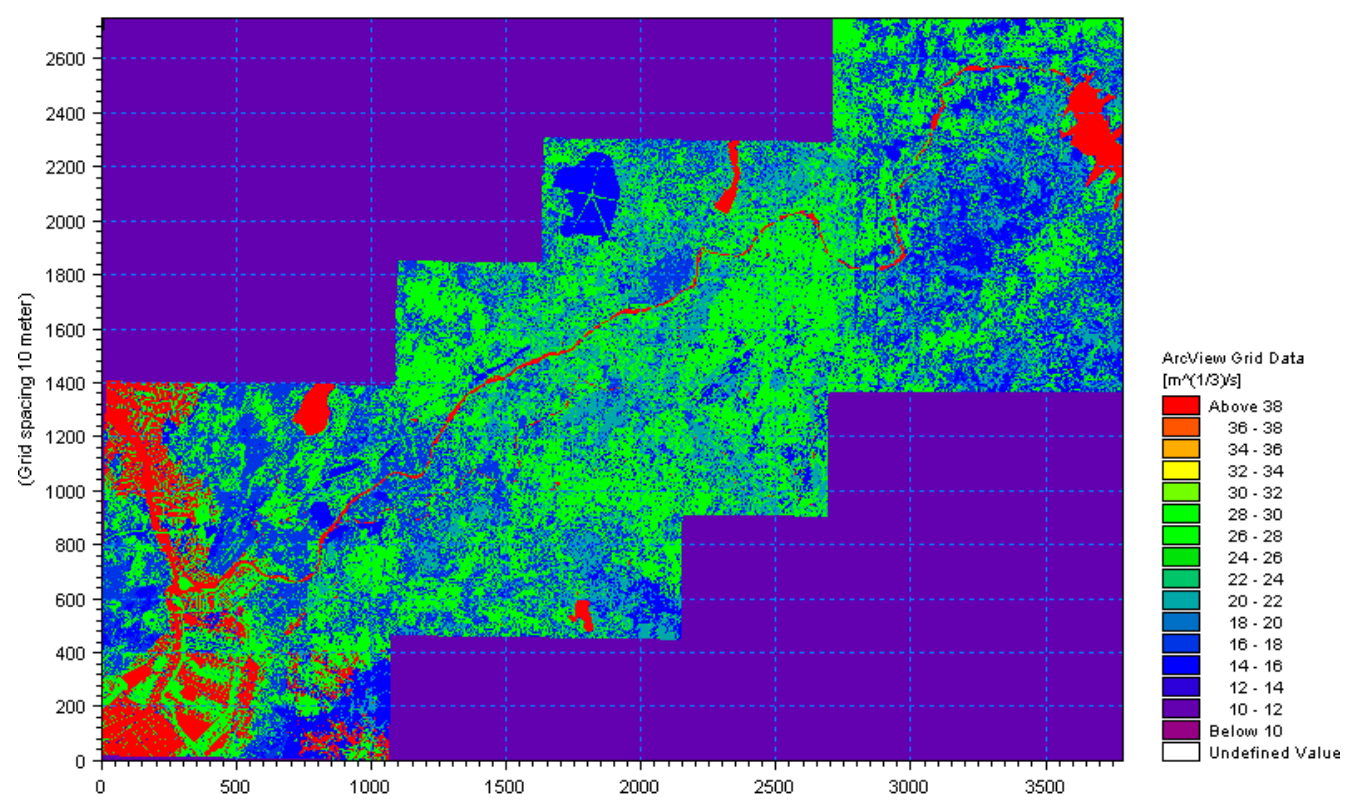

Figure 3. Manning map of the study area.

\subsection{Mapping of River Flood Risk and Evacuation Plans}

The flood risk maps are drawn by GIS [3,52]. The flood arrival time, inundation range, inundation depth, topography, roads and settlements obtained from the model are imported into GIS to create visualized flood risk maps. For clear presentation, the flood risk map only shows the arrival time, inundation extent, and inundation depth. Further, this paper uses the flood risk map to develop risk Evacuation plans. First, the risk units (settlements that may be inundated) are identified based on the flood risk map. Second, analyze the existence and capacity of resettlement units (settlements that will not be flooded) in the immediate area of the risk unit. As far as possible, the residents of the same risk unit should be relocated to the same resettlement unit. Third, the common ways of migration (by vehicle, on foot) and road capacity within the risk unit are examined. Fourth, the evacuation plan is determined with the goal of shortest path and least time.

\section{Results}

\subsection{Processes and Risks of Flood in River under Exceeding Control Standard Floods}

Fuzhouhe river suffered a typical flood with the peak flow of $1080 \mathrm{~m}^{3} / \mathrm{s}$ (20-year return period) in Guanjiatun hydrological station in 2012. The river cross section was measured in 2013 which is considered to changed less compared with 2012. This paper uses this flood event to determine MIKE 11 model parameters.

The results are shown in Figure 4 . The mean error between the fitting and measured values is $0.21 \mathrm{~m}$, the maximum error is $0.44 \mathrm{~m}$, and the minimum error is $0.06 \mathrm{~m}$. It indicates that the model achieves a satisfactory degree of accuracy and can be used to delineate the flood process in river. Next, the four scenarios of exceeding control standard floods are simulated to analyze the flood risk. 

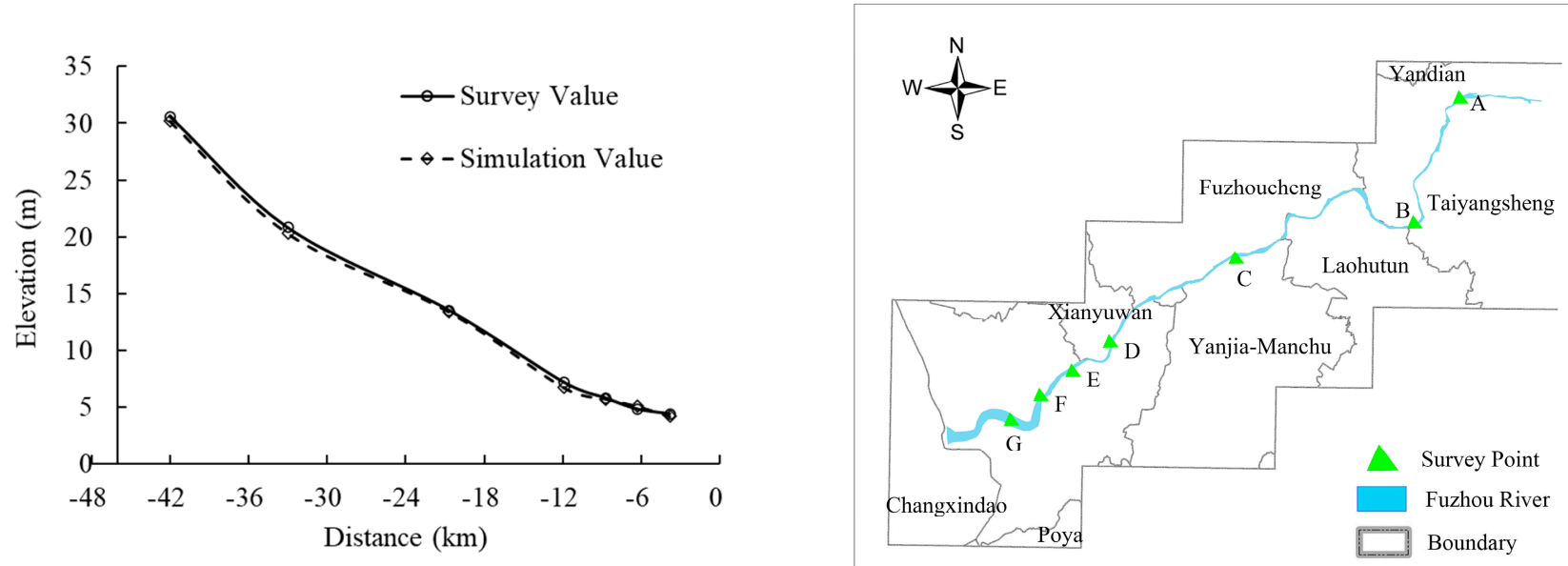

Figure 4. Simulated and observed values of river flood water level in 2012.

As shown in Figure 5, river levels are higher than both bank embankments in all scenarios, and the dyke is at the risk of inundation in several river sections. River flood risk is relatively low in the 20-year return period scenario, and the average elevation of the embankment is higher than the average flood discharge level in river channel during flood process. However, the average river water level on the right bank in the 50-year return period scenario is higher than the average elevation of the embankment, indicating a potentially hazardous situation. Further, the maximum differences between the flood discharge level and the left bank levee elevation for the floods of 20-year, 50-year, 100-year and 200-year return periods are $2.31 \mathrm{~m}, 2.97 \mathrm{~m}, 3.55 \mathrm{~m}$ and $4.44 \mathrm{~m}$, respectively, and the maximum differences on the right bank are $1.08 \mathrm{~m}, 1.99 \mathrm{~m}, 2.99 \mathrm{~m}$ and $3.89 \mathrm{~m}$, respectively. It can be seen that the lower the flood frequency, the higher the river flood risk. Generally, the left bank has a higher risk, and the location of the breaches are mainly concentrated in the downstream reaches. One-dimensional hydrodynamic simulation can competently identify the river risks, but the impacts of embankment $b$ reach is ignored. The river flood will spread along the breach and inundate the depressions in the basin [47]. Thus, this paper further couples the one-dimension and two-dimension models by using the Mike Flood model to analyze the dynamic flood process using indicators with submerged depth, submerged area and arrival time, and identify the risk in the watershed.
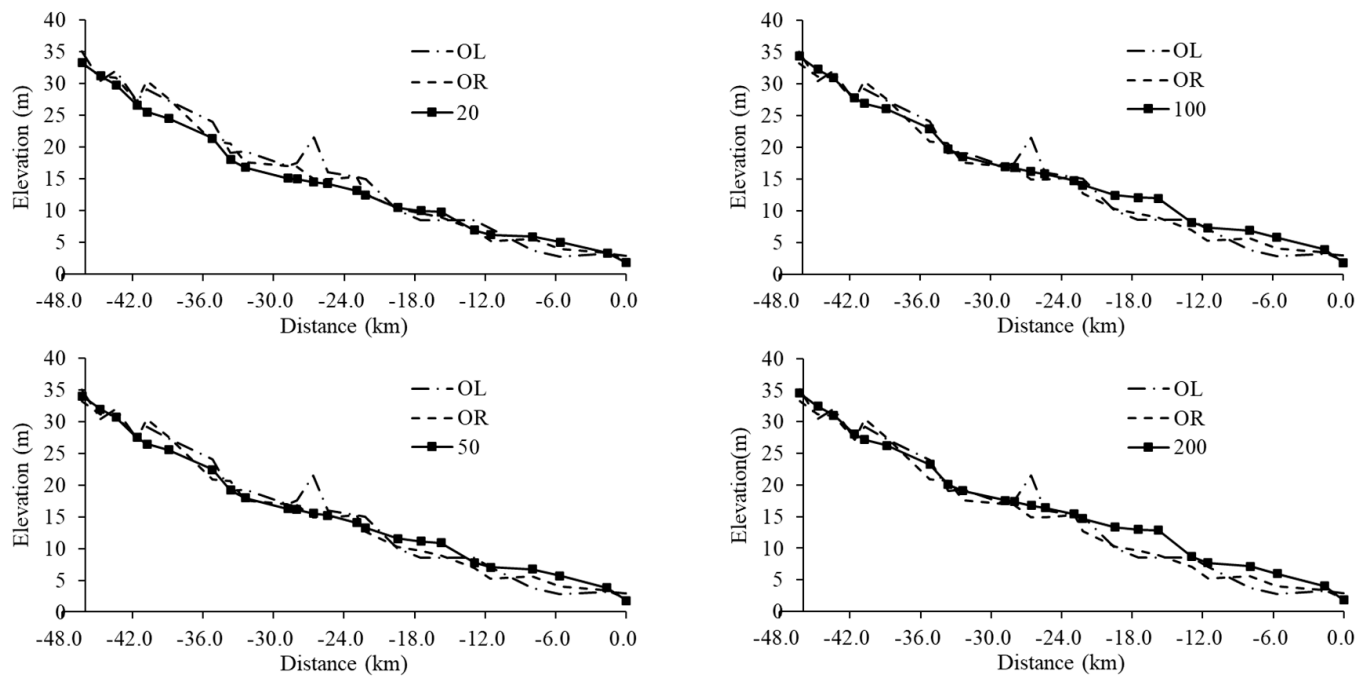

Figure 5. Simulation results of river flood of different frequencies (OL means elevation of original left bank of the river, OR means elevation of original right bank of the river, Numbers mean water level of simulation of results of different frequencies). 


\subsection{Dynamic Processes of Submerged Area in Floodplain under Exceeding Control Standard Floods}

The flood will spread to the floodplain along the breach and inundate the depressions, which can be considered as the two-dimensional hydrodynamic evolution of flood in floodplain [4,9] The MIKE FLOOD model is used to combine the one-dimension model and two-dimension model to simulate the flood process in the floodplain. The results suggest that overflowing starts after $6 \mathrm{~h}$ in the four cases, and this time is taken as the starting point of outflow in floodplain and recorded as 0th hour.

The simulation results show that the submerged area of different frequency floods gradually increases with time until the flood peak subsides (Figure 6). The growth rates of submerged area are increased with the flood peak level and the time of maximum inundation extent appears earlier. The growth rates of submerged area for the floods of 20-year, 50-year, 100-year, and 200-year return periods are $1.53 \mathrm{~km}^{2} / \mathrm{h}, 2.44 \mathrm{~km}^{2} / \mathrm{h}$, $2.92 \mathrm{~km}^{2} / \mathrm{h}$ and $3.29 \mathrm{~km}^{2} / \mathrm{h}$, and the corresponding largest submerged areas are $38.63 \mathrm{~km}^{2}$ at the 24th hour, $61.60 \mathrm{~km}^{2}$ at the 24th hour, $68.20 \mathrm{~km}^{2}$ at the $22 \mathrm{nd}$ hour, and $72.80 \mathrm{~km}^{2}$ at the 21st hour. Obviously, a larger flood produces a larger flood submerged area, and the inundation range of the 200-year frequency flood is 1.8 times of the 20-year frequency flood. Therefore, the impact of different frequency floods needs to be considered when developing emergency plans. The inundation area is affected by hydrodynamics. Some areas might be inundated at the beginning of the flood, and subsequently become non-inundated as the flood spreads to other depressions $[15,28]$. The actual inundation area should include regions that suffered inundation throughout the flood process, which means that the actual inundation area is probably larger than the simulation results of each time [16].

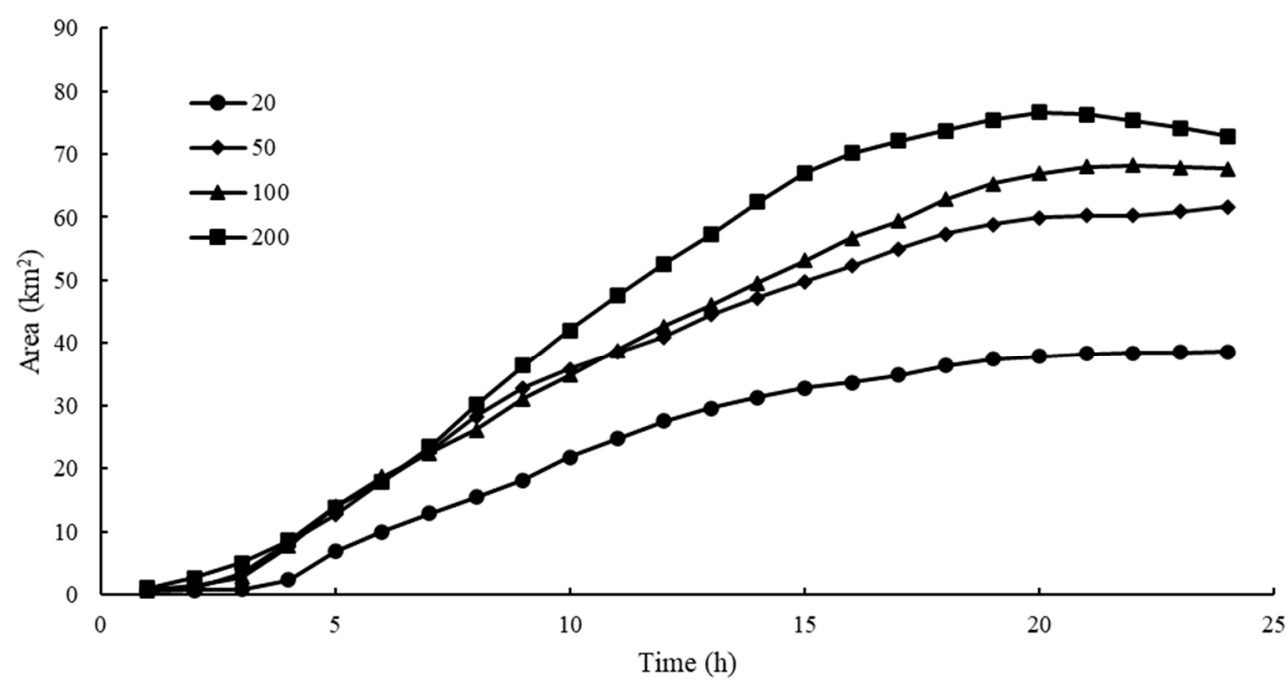

Figure 6. The dynamic change of submerged area of different frequency floods.

\subsection{Dynamic Processes of Submerged Depth in Floodplain during Exceeding Control Standard Floods}

Similarly, the coupled hydrodynamic model, MIKE FLOOD is used to calculate the change of submerged depth of different frequency floods.

As is illustrated by Figure 7, the trend of the submerged depth of different frequency floods in Fuzhouhe River is similar, starting with a sharp decline, followed by a small increase, and finally a steady decrease. The submerged depth at the very beginning is the largest because the submerged area is small and the distribution of the flooded areas is concentrated. Subsequently, the low-lying areas are quickly and preferentially filled with floodwater [53]. The submerged depth decreases with the increase of inundation extent. With the arrival of flood peak at the 7th hour, the submerged depth increases again and reaches its maximum at 9th hour. Finally, the submerged depth gradually decreases as the flood peak subsides. Simulation results show that the average submerged depth of four frequency flood is about $1.4 \mathrm{~m}$, and it might be affected by the elevation of the area. 
The narrow difference in maximum inundation depths for 4 frequency floods validate the viewpoint, which are $2.2 \mathrm{~m}, 2.0 \mathrm{~m}, 2.1 \mathrm{~m}$, and $1.9 \mathrm{~m}$ for 20-, 50-, 100-, and 200-year frequency floods, respectively. It is quite interesting that the submerged depth of 20-year return period scenario is even greater than that of the 200-year return period scenario, especially at the very beginning. The inundation area in the 1 st hour after the outflow of the 20-year return period scenario is $67.7 \mathrm{ha}$, while that of the 200-year return period scenario is 108.09 ha. A larger submerged area indicates that flood water moves higher up, which reasonably explains the decrease in inundation depth $[35,53]$. Therefore, submerged depth changes constantly during flood evolution and is affected by terrain, water resistance structure and flood process, which should be taken into considered when making contingency plans.

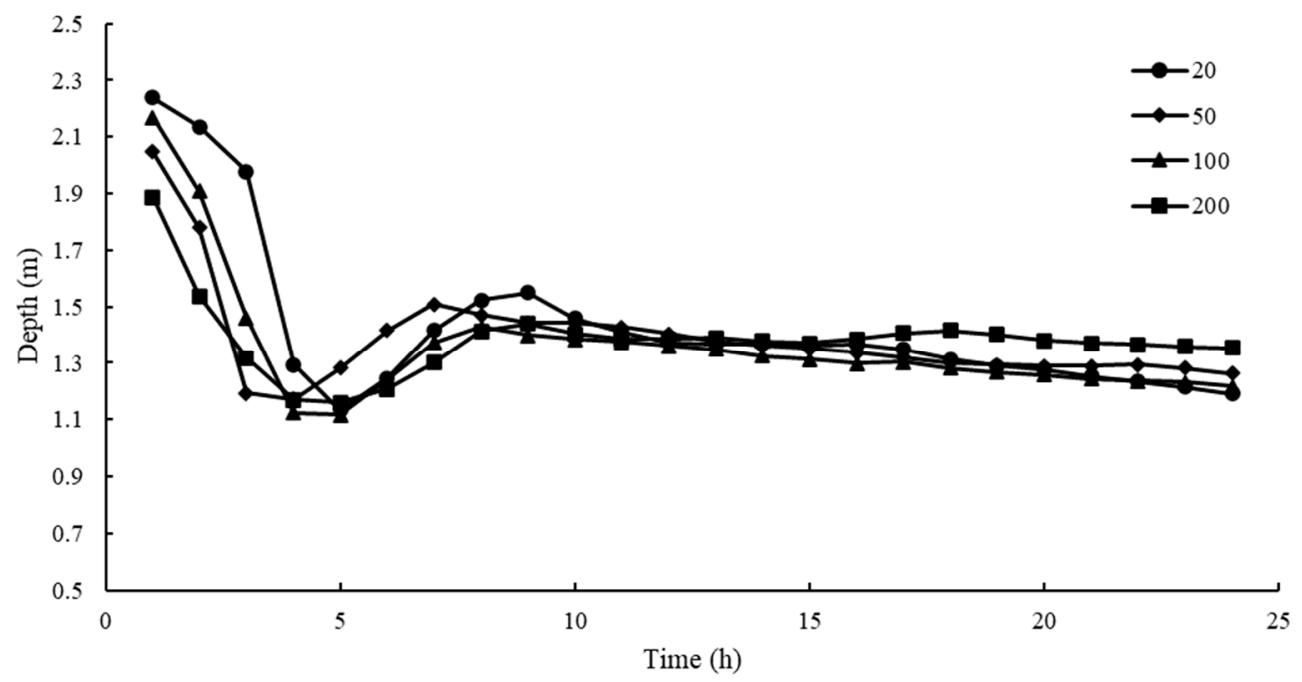

Figure 7. The dynamic change of submerged depth during different frequency floods (Depth in here means hourly average depth of submerged area).

\section{Discussion}

\subsection{Mapping of River Flood Risk and Analysis of Exceeding Control Standard Floods}

The submerged area and depth show dynamic changes throughout the flooding process [31]. From the perspective on risk, any area that has ever experienced inundation during the flood process is potentially at a risk [34]. Generally, the deeper the submerged depth, the higher the flood risk. In addition, flood arrival time is also closely related to the flood control and disaster reduction [46]. Thus, the flood risk maps of the three risk elements (area, depth, time) are created by GIS.

The submerged area increases with flood peak. The maximum inundation ranges of 20-, 50-, 100- and 200-year frequency floods are $42.73 \mathrm{~km}^{2}, 65.95 \mathrm{~km}^{2}, 74.86 \mathrm{~km}^{2}$ and $82.71 \mathrm{~km}^{2}$, respectively. Flood arrival time suggests that small submerged area appears within five hours after the overflow appears, and more than half areas can be submerged within $10 \mathrm{~h}$. Floods are blocked and arrived later in areas with roads or levees. The main submerged areas are concentrated in the estuary section and Fuzhoucheng section. Historical flood data in 2012 shows the main submerged area is close to the estuary area, and the upstream region is rarely submerged, which is consistent with the calculation results. The areas with greater inundation depths are the river breaches and the Yanjia-Manchu town. The inundation areas at breaches are small due to the instantaneous diffusion of the flood. The terrain in Yanjia-Manchu town is lower which brings great risk of flooding. Next, the river flood maps of four scenarios are discussed.

Figures 8 and 9 clearly show that there are 7 breaches $(A, B, C, E, F, G$, and H) in the 20year return period scenario. The main submerged areas are concentrated in Fuzhoucheng and estuary region, and the submerged depth is greater on the left bank at breach $\mathrm{B}$. The real-world scenarios support this result. Six hours after model running, there is a breach at location $\mathrm{A}$, and the time is recorded as $0 \mathrm{~h}$. The submerged area at breach $\mathrm{A}$ is mainly 
concentrated on the left bank. The submerged depth is about 2.0-3.0 m near the riverbank, and is about $0-1.5 \mathrm{~m}$ in other areas. Breach happens after $1.5 \mathrm{~h}$ and spreads at breach C. The submerged depth near the riverbank is deeper with a range of about 2.0 to $3.5 \mathrm{~m}$, and that in the other areas is about 0-1.0 m. Embankments burst after $4 \mathrm{~h}$ at breach $\mathrm{E}$ and $H$. The submerged range is mainly concentrated near the riverbank, and the range is smaller compared with the other breaches. The submerged depth is about 2.0-5.0 m near the riverbank and is about $0-1.0 \mathrm{~m}$ in other areas. Effusion appears at breach $\mathrm{B}$ after $4.5 \mathrm{~h}$ and expands to banks. The inundation range and submerged depth on the left bank is greater than that on the right bank. The submerged depth is deeper and is about $5.0-10.0 \mathrm{~m}$ near the left bank, and that in the other area is about $2.0-4.0 \mathrm{~m}$. The submerged depth is about 1.5-2.5 m near the right bank, and the other area is about 0-1.5 m. Overflow occurs at the embankment after $7 \mathrm{~h}$ at breach $\mathrm{G}$, and the inundation range is concentrated within a small area on the right bank. The submerged depth is deeper and the range is between 5.0-8.0 m near the river bank, and the other area is about 0-1.5 m. Flood water rushes out breach $\mathrm{F}$ after $12.5 \mathrm{~h}$, and spreads within a small area on both sides of the river. The submerged depth is deeper and varies from $2 \mathrm{~m}$ to $7 \mathrm{~m}$ near the right bank, and the other area is about $0-1.5 \mathrm{~m}$. The submerged depth is shallow and is about $1-2 \mathrm{~m}$ near the left bank, and the other area is about $0-1.5 \mathrm{~m}$.

As can be seen in Figures 10 and 11, compared with the 20-year return period scenario, the breaches appear earlier in the 50-year return period scenario, and the submerged depth increases in some areas. The inundation ranges increase at breach A, E, and F, which mainly exist on the left bank. At breach $\mathrm{A}$, the submerged area and submerged depth increase in the left bank compared with the 20-year return period scenario. The submerged depth is about $2.0-3.5 \mathrm{~m}$ in the left bank and that in the other area is about $0-2.0 \mathrm{~m}$ at breach $\mathrm{A}$. Embankment bursts after $0.5 \mathrm{~h}$ at breach $\mathrm{C}$, which arrives two hours earlier than that of the 20-year return period scenario. The submerged depth is deeper and is about 2-3.5 m near the riverbank, and the other areas is about $0-1.5 \mathrm{~m}$. Embankment burst happens after $4 \mathrm{~h}$ at breach E, and the submerged depth is about 1.0-2.5 m near the riverbank. In contrast with the 20-year return period scenario, the main submerged area is concentrated on the left bank, and the submerged depth on the left bank region $(0-2.5 \mathrm{~m})$ is also greater than that on the right bank $(0-1.0 \mathrm{~m})$. For breach $\mathrm{H}$, the result of 50 -year return period scenario is similar to the 20-year return period scenario. The breach appears after $4 \mathrm{~h}$ at breach $\mathrm{B}$, which is half an hour earlier than that of the 20-year flood. Breach happens after $6.5 \mathrm{~h}$ at breach $\mathrm{F}$, which arrives six hours earlier than that of the 20-year flood. Except the arriving time, the other indicators for breach B and F are similar to that of the 20-year return period scenario.

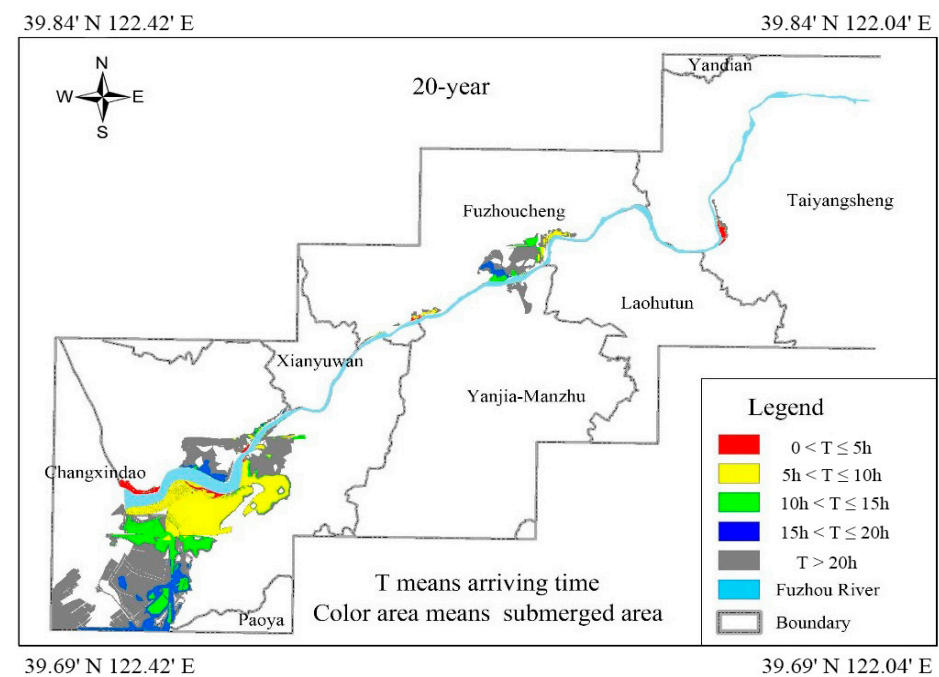

Figure 8. Flood arrival time and submerged area of 20-year return period scenario. 


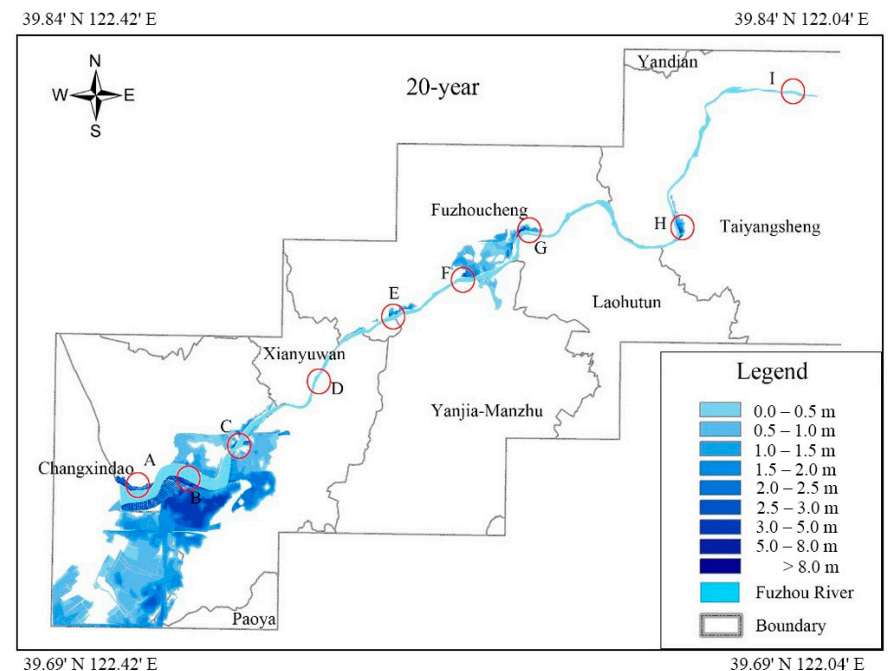

Figure 9. Submerged depth of 20-year return period scenario (Depth in here means maximum depth of the same point during the total flood process).

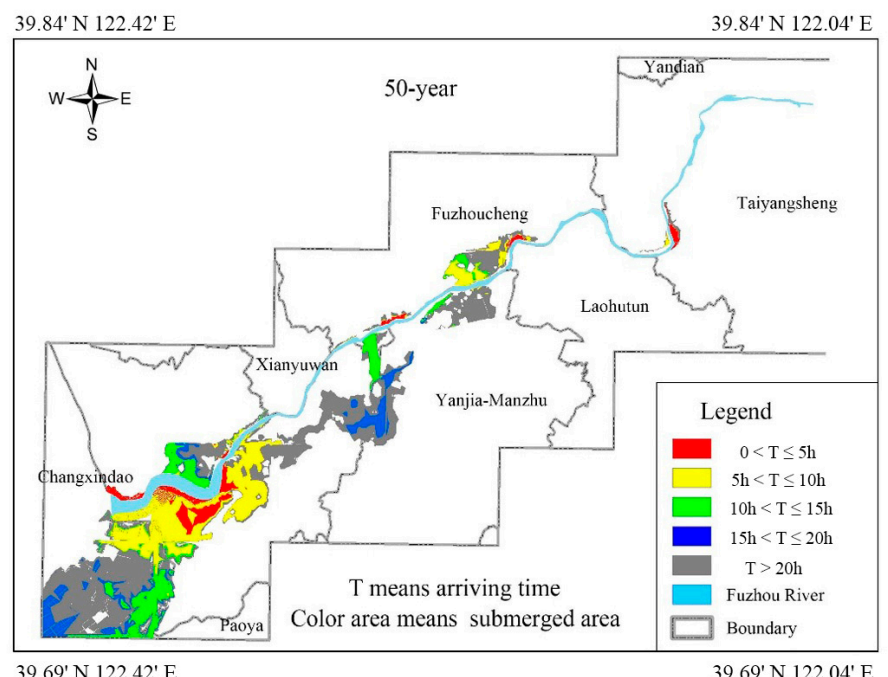

Figure 10. Flood arrival time and submerged area of 50-year return period scenario.

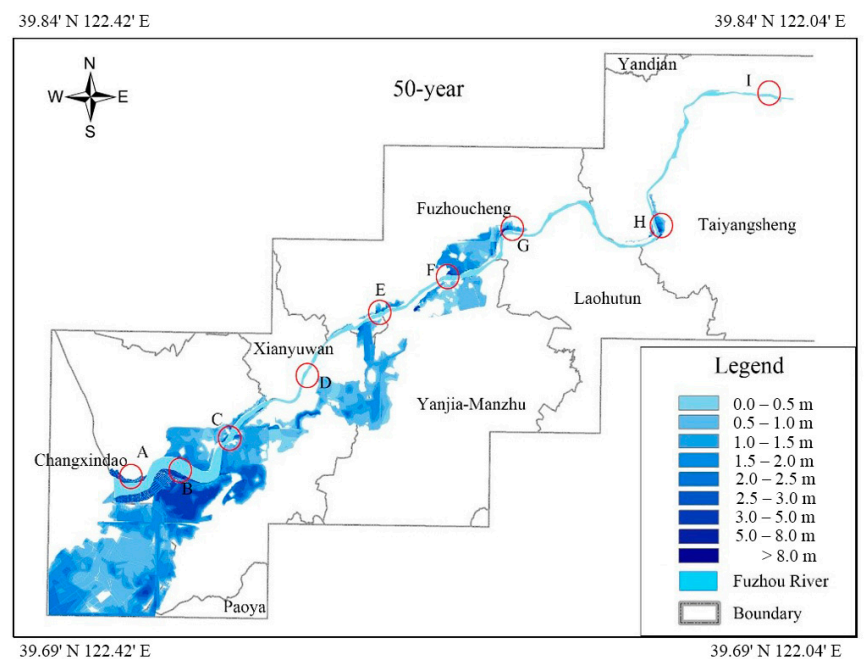

Figure 11. Submerged depth of 50-year return period scenario (Depth in here means maximum depth of the same point during the total flood process). 
Figures 12 and 13 show that two new breaches appear in the 100-year return period scenario, i.e., $\mathrm{D}$ and $\mathrm{I}$. The inundation area of this scenario expands significantly. The submerged depth and area of breach A, B, C, F, G, and H are similar to those of the 50-year return period scenario. The submerged depth on the left bank at breach $\mathrm{E}$ are greater than those of the 50-year return period scenario. Compared with the 50-year return period scenario, the occurrence of breach for breach E, G and $\mathrm{H}$ in the upstream area is $5 \mathrm{~h}, 1.5 \mathrm{~h}$, and $2 \mathrm{~h}$ earlier, while that for the downstream breach $\mathrm{B}$ and $\mathrm{C}$ are $1.5 \mathrm{~h}$ and $3.5 \mathrm{~h}$ later. This difference can be explained by flood diversion. The high-volume runoff and the newly emerged breaches accelerate flood spread in the upstream floodplain and meanwhile reduce the downstream flood discharge.

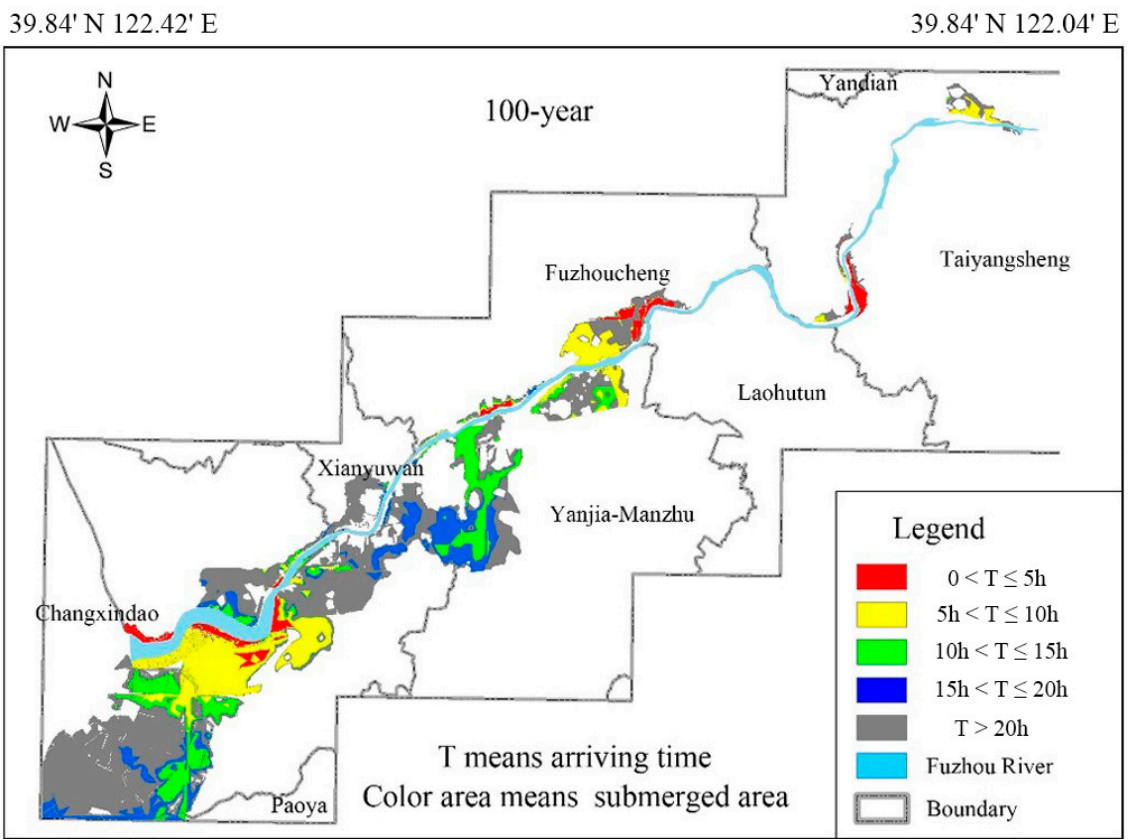

39.69' N 122.42' E

$39.69^{\prime} \mathrm{N} 122.04^{\prime} \mathrm{E}$

Figure 12. Flood arrival time and submerged area of 100-year return period scenario.

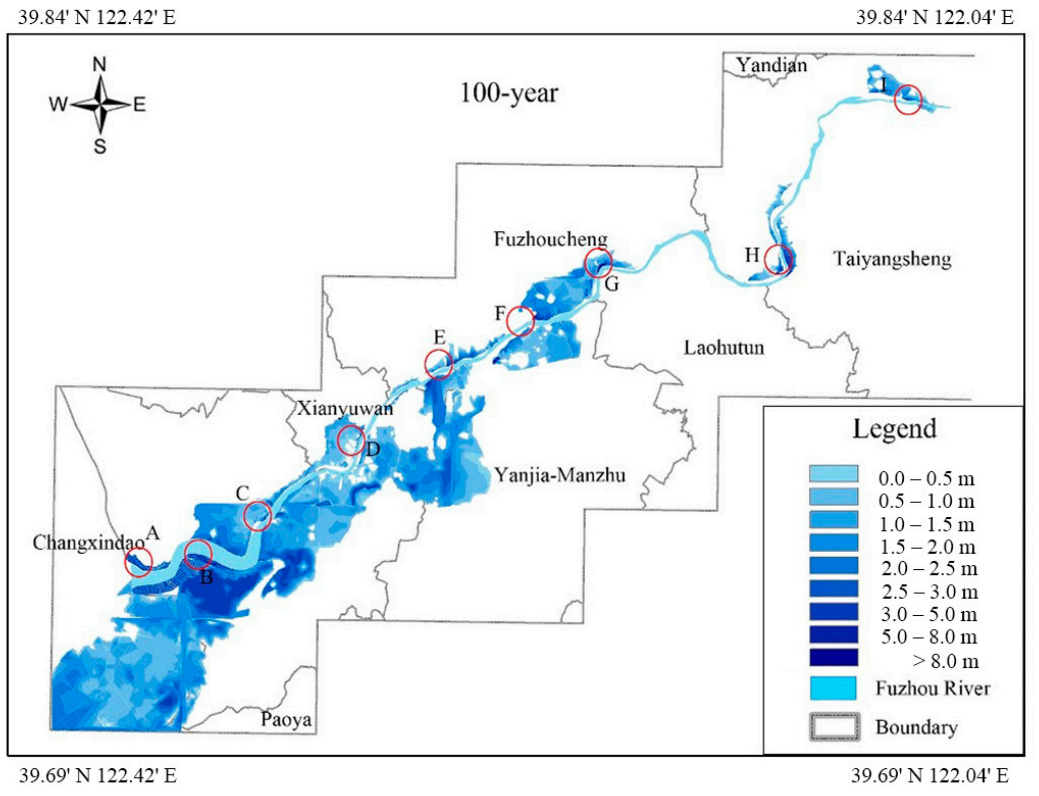

Figure 13. Submerged depth of 100-year return period scenario (Depth in here means maximum depth of the same point during the total flood process). 
As can be seen in Figures 14 and 15, the overall inundation situation is similar to that of a 100-year return period scenario. Similarly, the occurrence at upstream breaches $\mathrm{D}$, E, F, G, H, and I are $5 \mathrm{~h}, 0.5 \mathrm{~h}, 1.5 \mathrm{~h}, 0.5 \mathrm{~h}, 0.5 \mathrm{~h}$, and $2 \mathrm{~h}$ earlier. While the downstream breaches $B$ and $C$ are $0.5 \mathrm{~h}$, and $3 \mathrm{~h}$ later, respectively. In addition, the submerged depth in breach $\mathrm{E}$ on the left bank is about $1.0-3.5 \mathrm{~m}$ and is greater than that of the 100-year return period scenario.

$39.84^{\prime} \mathrm{N} 122.42^{\prime}$

39.84 ' N 122.04' E

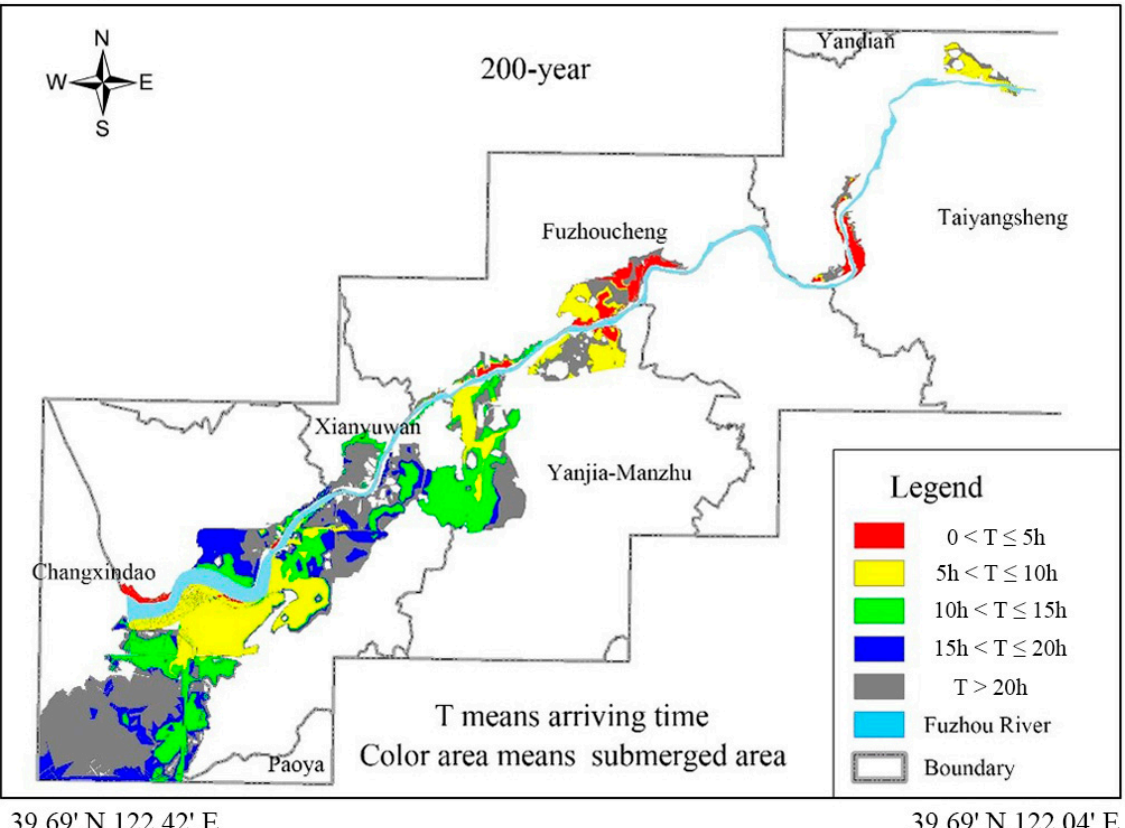

Figure 14. Flood arrival time and submerged area of 200-year return period scenario.

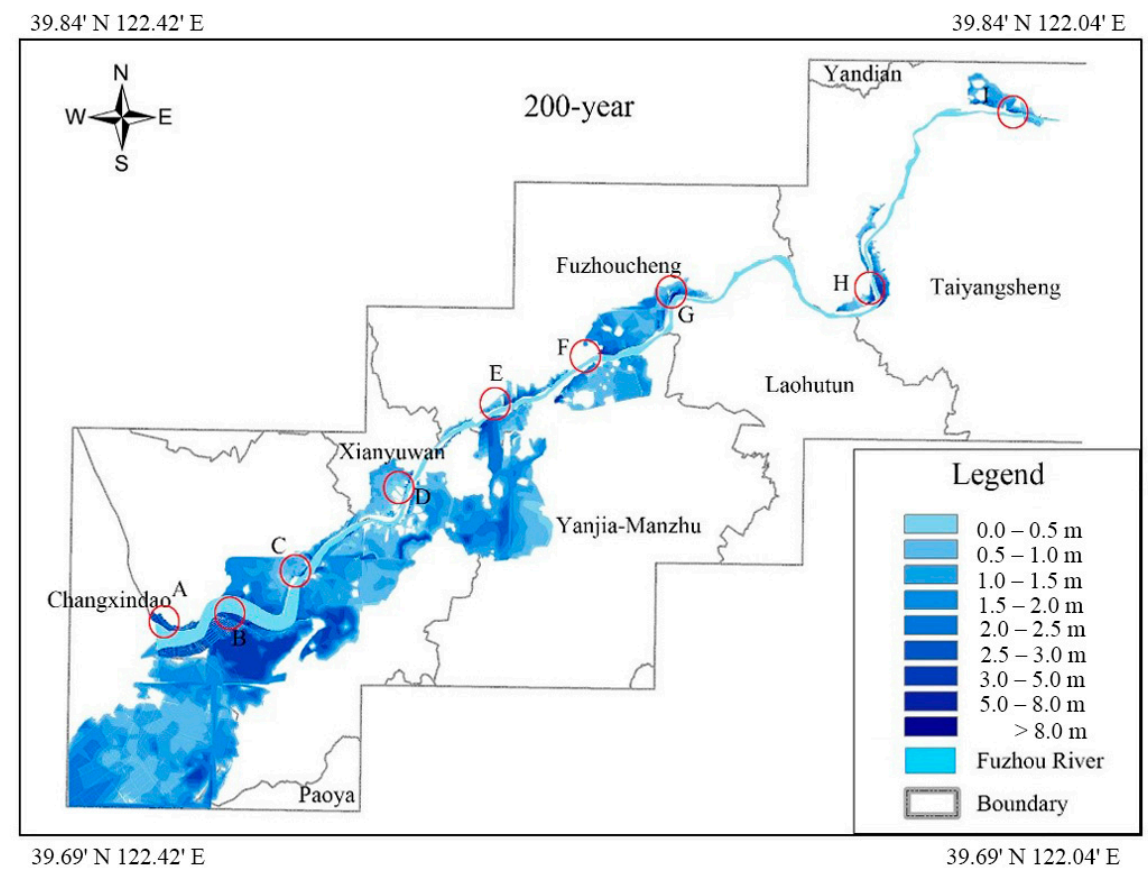

Figure 15. Submerged depth of 200-year return period scenario (Depth in here means maximum depth of the same point during the total flood process).

Above all, the characteristics of dynamic change of flood should not be neglected during the assessment of flood risk. Flood risk map can be used to identify the locations of breaches clearly, which helps to reduce flood losses and make escape routes. 


\subsection{Evacuation Plans for Exceeding Control Standard Floods}

In this section, this paper analyzes the risk maps of different frequency floods to identify the risk units (areas might be submerged) and the optimal resettlement units (noninundation areas). The flood process, evacuation time, migration path, topography, and resettlement capacity are considered when developing evacuation routes [54]. The study area is located in villages and evacuation on foot, or by tractor and car are the most common ways. In order to evacuate the risk areas as soon as possible, the migration distance is limited to $4 \mathrm{~km}$, the average migration distance is about $2 \mathrm{~km}$, the evacuation time for vehicles is limited to $20 \mathrm{~min}$, and the walking time is set to be $70 \mathrm{~min}$.

As is shown in Figure 16, the submerged area is small and the main risk units are distributed in Najiatun, Xilanqi, Xiaohedong, Donglanqi, Houshili and Xidian in 20-year return period scenario. These risk units will be relocated to the non-inundated areas including Shijiabao, Xibeiying, Gaolicheng, Gaolicheng, Dafangsheng and Haidao (resettlement units) to avoid the risk of flood.

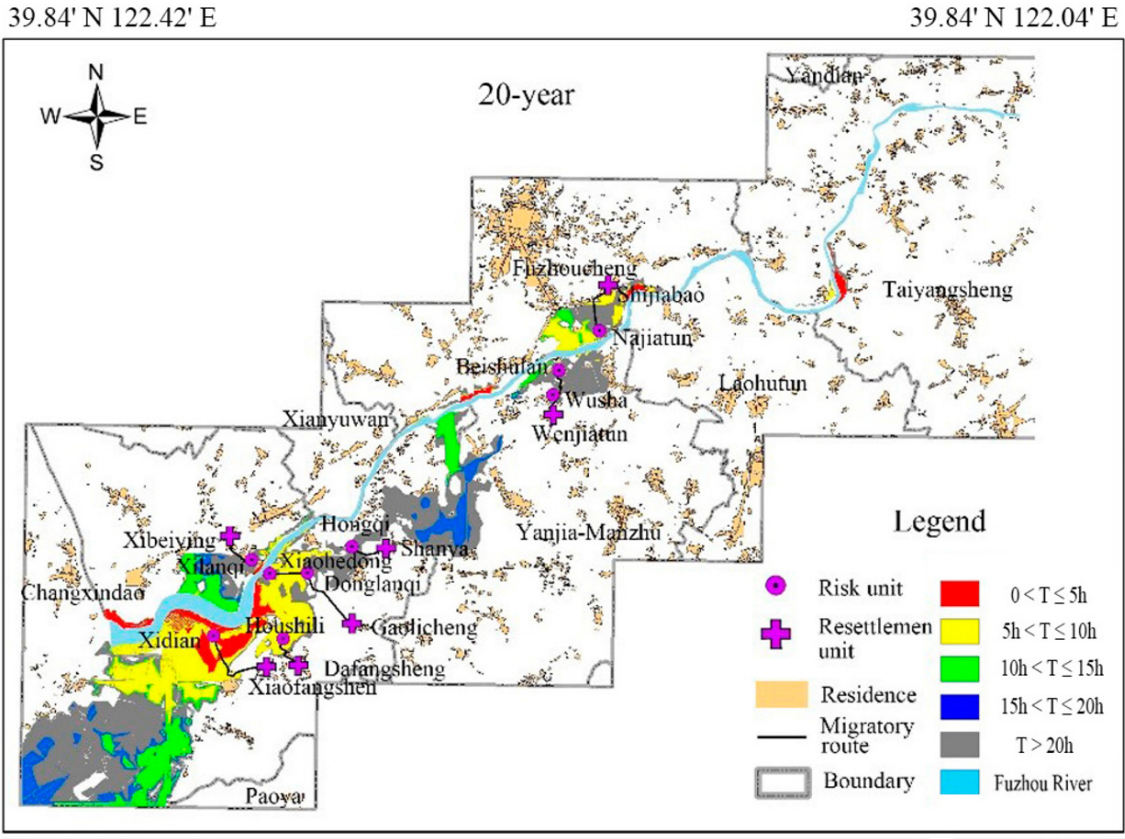

$39.69^{\prime} \mathrm{N} 122.42^{\prime} \mathrm{E}$

$39.69^{\prime} \mathrm{N} 122.04^{\prime} \mathrm{E}$

Figure 16. Evacuation plan of 20-year return period scenario.

Similarly, evacuation plans for the other flood scenarios can be developed (Figures 16-19, Table 3). There are six risk units and five resettlement units for the 20-year return period scenario, the average migration distance is $2.25 \mathrm{~km}$ and excavation time on foot is about $37 \mathrm{~min}$. For the 50-year return period scenario, there are nine risk units and seven resettlements, with an average migration distance of $2.00 \mathrm{~km}$ and evacuation time on foot of about 33 min. There are 14 risk units and 10 resettlement units for the 100-year return period scenario and 200-year return period scenario, with an average migration distance of $2.06 \mathrm{~km}$ and evacuation time on foot of about $34 \mathrm{~min}$. 


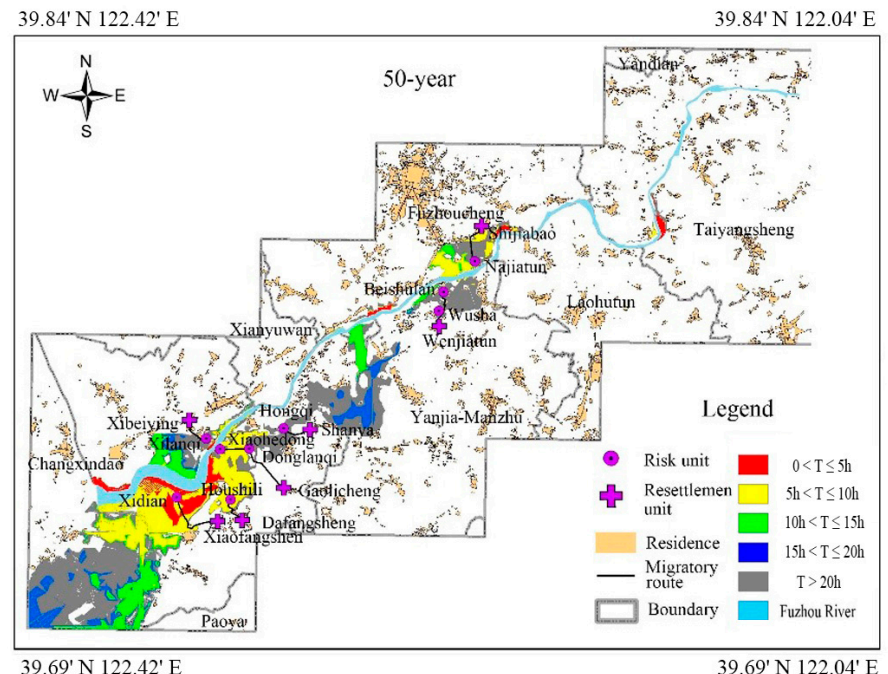

Figure 17. Evacuation plan of 50-year return period scenario.

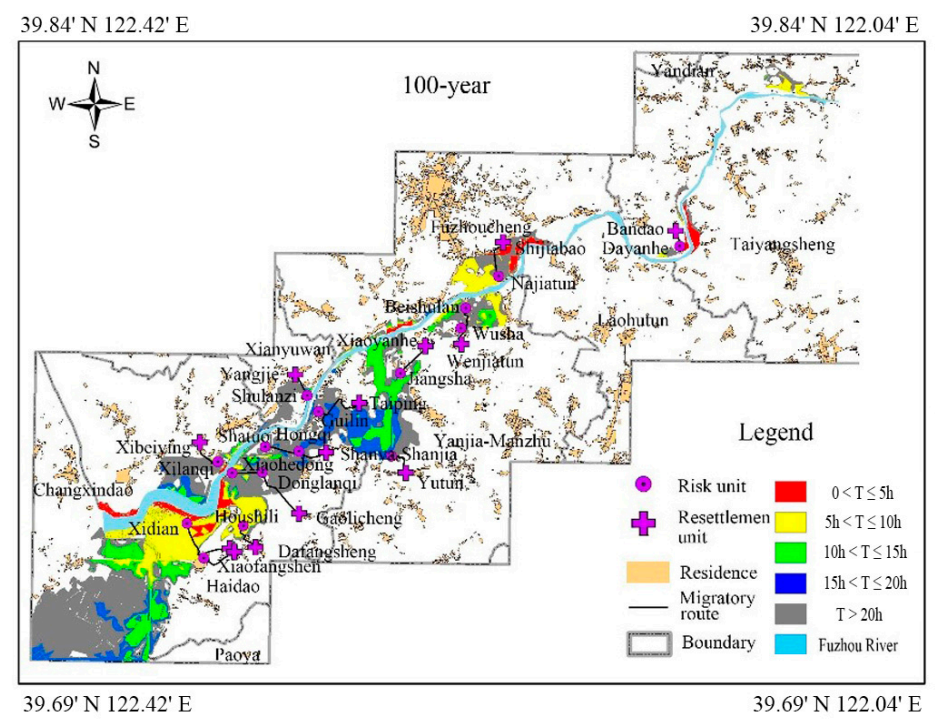

Figure 18. Evacuation plan of 100-year return period scenario.

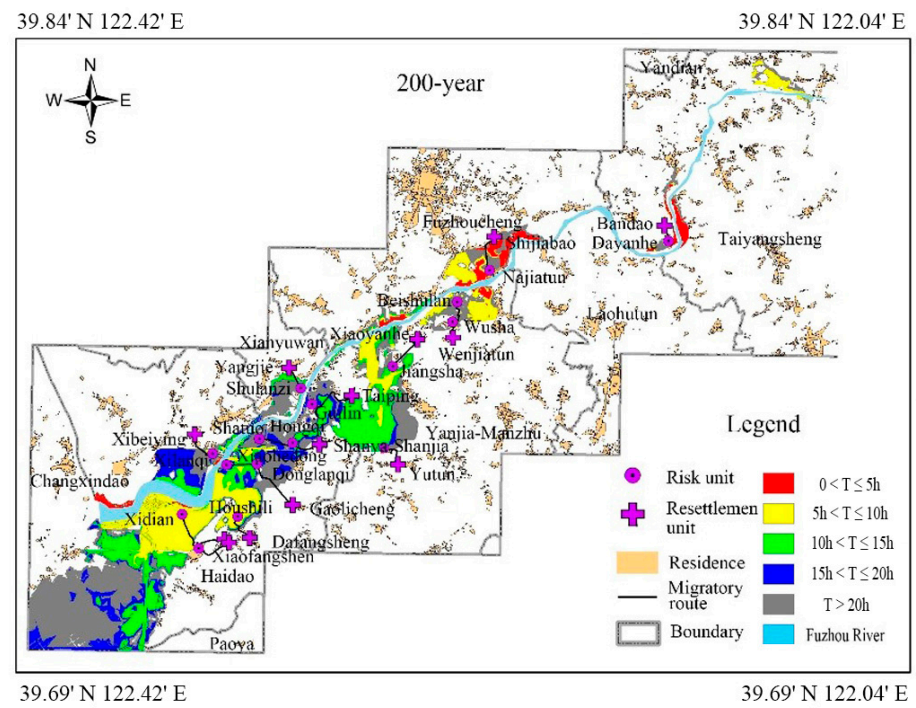

Figure 19. Evacuation plan of 200-year return period scenario. 
Table 3. Information of Emergency plans.

\begin{tabular}{ccccccc}
\hline Order & Risk Unit & Migration Distance $(\mathbf{m})$ & VET (min) & WT (min) & Resettlement Unit & Frequency \\
\hline 1 & Najiatun & 1747 & 9.1 & 29.1 & Shijiabao & $20,50,100,200$ \\
2 & Xilanqi & 1529 & 7.6 & 24.6 & Xibeiying & $20,50,100,200$ \\
3 & Xiaohedong & 4001 & 20.6 & 66.7 & Gaolicheng & $20,50,100,200$ \\
4 & Donglanqi & 2626 & 13.5 & 43.8 & Gaolicheng & $20,50,100,200$ \\
5 & Houshili & 1437 & 7.4 & 23.9 & Dafangsheng & $20,50,100,200$ \\
6 & Xidian & 2141 & 11.1 & 35.7 & Haidao & $20,50,100,200$ \\
7 & Beishulan & 2031 & 10.4 & 33.9 & Wenjiatun & $50,100,200$ \\
8 & Wusha & 1013 & 5.2 & 16.9 & Wenjiatun & $50,100,200$ \\
9 & Hongqi & 1458 & 7.5 & 24.3 & Shanya & $50,100,200$ \\
& Dayanhe & 736 & 3.8 & 12.3 & Bandao & 100,200 \\
10 & Jiangsha & 1707 & 13.8 & 28.5 & Xiaoyanhe & 100,200 \\
11 & Guilin & 2653 & 5.5 & 18.1 & Taiping & 100,200 \\
12 & Shulanzi & 1077 & 14.8 & 48.1 & Yangjie & 100,200 \\
13 & Shatuo & 2883 & 7.5 & 24.3 & Shanya & 100,200 \\
14 & Shanjia & 1457 & 17.2 & 55.7 & Xutun & 100,200 \\
15 & Xidian & 3340 & 8.6 & 28 & Xiaofangsheng & 100,200 \\
16 & Haidao & 1682 & & 1000 & 100,200 \\
\hline
\end{tabular}

Note: VET means vehicle evacuation time; WT means walking time.

The study area of this paper, Fuzhou River basin, is dominated by villages and towns, and the main consideration in the development of the evacuation plan is personal safety. In fact, flood hazards are multifaceted, involving human safety, residential property damage, agriculture, forestry, fishery, etc. [55-57]. Flood vulnerability evaluation and flood damage evaluation also contribute to the development of risk avoidance plans [58]. Analysis of basic information including slope, elevation, distance from open channel streams, distance from totally covered streams, hydrolithology, land cover is useful for the assessment of the flood risk in the data scarce area $[59,60]$. In addition to management measures, preplans should be constructed for embankments prone to breaches in the event of over-standard flooding in small and medium-sized rivers for timely repair of embankments. Flood disaster loss can be minimized by combining engineering and management hazard reduction measures.

\section{Conclusions}

This paper takes Fuzhouhe river as an example to analyze the process of exceeding control standard flood risk through hydrodynamic model, draws the flood risk maps and develops the evacuation plans.

(1) There is a risk of overflowing in the event of exceeding control standard floods (20-, 50-, 100-, 200-year frequency), and the risk is higher on the left bank.

(2) The submerged area of different frequency floods gradually increases with time until the flood peak subsides. In addition, the growth rate of submerged area rises with the increase of flood peak. The increasing rates of submerged area for the return periods of 20-year, 50-year, 100-year and 200-year are $1.53 \mathrm{~km}^{2} / \mathrm{h}, 2.44 \mathrm{~km}^{2} / \mathrm{h}, 2.92 \mathrm{~km}^{2} / \mathrm{h}$ and $3.29 \mathrm{~km}^{2} / \mathrm{h}$, and the corresponding largest submerged area are $38.63 \mathrm{~km}^{2}$ at the 24th hour, $61.60 \mathrm{~km}^{2}$ at the 24th hour, $68.20 \mathrm{~km}^{2}$ at the $22 \mathrm{nd}$ hour, and $72.80 \mathrm{~km}^{2}$ at the 21st hour.

(3) The change of submerged depths of different frequency floods are similar and show a downward-upward-downward trend. The average submerged depth of four frequency floods is about $1.4 \mathrm{~m}$.

(4) Three flood risk maps of flood risk elements (arrival time, submerged area and submerged depth) of different frequency floods are created using GIS to realize the visual analysis of flood risk. The submerged areas for the floods of 20-year, 50-year, 100-year and 200-year return periods are $42.73 \mathrm{~km}^{2}, 65.95 \mathrm{~km}^{2}, 74.86 \mathrm{~km}^{2}$ and $82.71 \mathrm{~km}^{2}$, respectively. The greatest inundation depth is at the river breaches and in the Yanjia-Manchu town. 
(5) The evacuation plans of four scenarios are developed based on flood risk maps, taking consideration of excavation time, migration path, topography, and resettlement capacity. The risk units and identified resettlement units are set for each scenario. The migration distance is limited within $4 \mathrm{~km}$, and the average relocation distance is about $2 \mathrm{~km}$. The maximum evacuation time by vehicles is $20 \mathrm{~min}$, and the maximum evacuation time on foot is set to be about $70 \mathrm{~min}$.

\begin{abstract}
Author Contributions: Conceptualization, T.W.; methodology, T.W. and Z.W.; software, Z.W.; validation, Y.S., X.S., C.L. and T.W.; formal analysis, Z.W. and Y.S.; investigation, Y.S. and X.S.; resources, T.W.; data curation, T.W.; writing —original draft preparation, T.W.; writing — review and editing, Z.W., Y.S. and X.L.; visualization, Z.W. and L.J.; supervision, T.W.; project administration, T.W.; funding acquisition, T.W. All authors have read and agreed to the published version of the manuscript.
\end{abstract}

Funding: This research was supported by the National Natural Science Foundation of China (Grant No. 51809032), the Fundamental Research Funds for the Central Universities (Grant No. DUT20RC(3)059), the Major Basic Research Project of the Natural Science Foundation of the Jiangsu Higher Education Institutions (Grant No. BK20191050) and the Opening Foundation of Jiangsu Smart Factory Engineering Research Center (Grant No. JSSFER2019A5, No. JSSFER2019A6), Foundation of Natural Science Foundation of Anhui Province of China (1808085ME158), Natural Science Research Project of Jiangsu Province Colleges and Universities (Grant No. 18KJD560001), Philosophy and Social Science Project of Jiangsu Province Colleges and Universities (Grant No. 2019SJA1659).

Data Availability Statement: Not applicable.

Acknowledgments: This research is supported by the Dongfeng reservoir administration, Dalian central marine station, and Wafangdian Water Resources Survey and Design Co. Ltd.

Conflicts of Interest: There is no conflict of interest that we know of for this work.

\title{
References
}

1. Manopiniwes, W.; Irohara, T. Optimization model for temporary depot problem in flood disaster response. Nat. Hazards 2021, 105, 1743-1763. [CrossRef]

2. Yin, C. Hazard assessment and regionalization of highway flood disasters in China. Nat. Hazards 2020, 100, 535-550. [CrossRef]

3. Lee, J.Y.; Son, H.J.; Kim, D.; Ryu, J.H.; Kim, T.W. Evaluating the Hydrologic Risk of n-Year Floods According to RCP Scenarios. Water 2021, 13, 1805. [CrossRef]

4. Zhang, Y.Y.; Chen, Q.T.; Xia, J. Investigation on flood event variations at space and time scales in the Huaihe River Basin of China using flood behavior classification. J. Geogr. Sci. 2020, 30, 2053-2075. [CrossRef]

5. Hartman, J. Engineers use basic tools to avert flooding disaster. Civ. Eng. 2001, 71, 27.

6. Chinnarasri, C.; Phothiwijit, K. Appropriate Engineering Measures with Participation of Community for Flood Disaster Reduction: Case of the Tha Chin Basin. Thailand. Arab. J. Sci. Eng. 2016, 41, 4879-4892. [CrossRef]

7. Oost, J.; Hoekstra, A.Y. Flood damage reduction by compartmentalization of a dike ring: Comparing the effectiveness of three strategies. J. Flood Risk Manag. 2009, 2, 315-321. [CrossRef]

8. Olson, K.R.; Morton, L.W. Runaway barges damage Marseilles Lock and Dam during 2013 flood on the Illinois River. J. Soil Water Conserv. 2014, 69, 104-109. [CrossRef]

9. Jones, D.K.; Zou, Q.; Reeve, D.E. Computational modelling of coastal flooding caused by combined surge overflow and wave overtopping on embankments. J. Flood Risk Manag. 2013, 6, 70-84. [CrossRef]

10. Verbeke, S.; Devroede, N. Flood risk management in Flanders: From flood risk objectives to appropriate measures through state assessment. Houille Blance 2017, 4, 20-25. [CrossRef]

11. Li, F.; Yan, X.F.; Duan, H.F. Sustainable Design of Urban Stormwater Drainage Systems by Implementing Detention Tank and LID Measures for Flooding Risk Control and Water Quality Management. Water Resour. Manag. 2019, 33, 3271-3288. [CrossRef]

12. Chen, J.; Zhong, P.A.; Liu, W.F.; Wan, X.Y.; Yeh, W.W.G. A multi-objective risk management model for real-time flood control optimal operation of a parallel reservoir system. J. Hydrol. 2020, 590, 125264. [CrossRef]

13. Handayani, W.; Chigbu, U.E.; Rudiarto, I.; Putri, H.I.S. Urbanization and Increasing Flood Risk in the Northern Coast of Central Java-Indonesia: An Assessment towards Better Land Use Policy and Flood Management. Land 2020, 9, 343. [CrossRef]

14. Rauter, M.; Kaufmann, M.; Thaler, T.; Fuchs, S. Flood risk management in Austria: Analysing the shift in responsibility-sharing between public and private actors from a public stakeholder's perspective. Land Use Policy 2020, 99, 105017. [CrossRef]

15. Ali, S.A.; Khatun, R.; Ahmad, A.; Ahmad, S.N. Application of GIS-based analytic hierarchy process and frequency ratio model to flood vulnerable mapping and risk area estimation at Sundarban region, India. Model. Earth Syst. Environ. 2019, 5, 1083-1102. [CrossRef] 
16. Jato-Espino, D.; Lobo, A.; Ascorbe, S.A. Urban flood risk mapping using an optimised additive weighting methodology based on open data. J. Flood Risk Manag. 2019, 12, 12533. [CrossRef]

17. Jakovljevic, G.; Govedarica, M.; Alvarez, T.F.; Pajic, V. Accuracy Assessment of Deep Learning Based Classification of LiDAR and UAV Points Clouds for DTM Creation and Flood Risk Mapping. Geoscience 2019, 9, 323. [CrossRef]

18. Kiedrzynska, E.; Kiedrzynski, M.; Zalewski, M. Sustainable floodplain management for flood prevention and water quality improvement. Nat. Hazards 2015, 76, 955-977. [CrossRef]

19. Bouska, K.L.; Lindner, G.A.; Paukert, C.P.; Jacobson, R.B. Stakeholder-led science: Engaging resource managers to identify science needs for long-term management of floodplain conservation lands. Ecol. Soc. 2016, 21, 12. [CrossRef]

20. Ahiablame, L.; Shakya, R. Modeling flood reduction effects of low impact development at a watershed scale. J. Environ. Manag. 2016, 171, 81-91. [CrossRef] [PubMed]

21. Huang, C.L.; Hsu, N.S.; Liu, H.J.; Huang, Y.H. Optimization of low impact development layout designs for megacity flood mitigation. J. Hydrol. 2018, 564, 542-558. [CrossRef]

22. Movahedinia, M.; Samani, J.M.V.; Barakhasi, F.; Taghvaeian, S.; Stepanian, R. Simulating the effects of low impact development approaches on urban flooding: A case study from Tehran, Iran. Water Sci. Technol. 2019, 80, 1591-1600. [CrossRef]

23. Dubea, T.; DeNecker, L.; Van, V.J.H.J.; Wepener, V.; Smit, N.J.; Brendonck, L. Spatial and temporal variation of invertebrate community structure in flood-controlled tropical floodplain wetlands. J. Freshw. Ecol. 2017, 32, 1-15. [CrossRef]

24. Mostafazadeh, R.; Sadoddin, A.; Bahremand, A.; Sheikh, V.B.; Garizi, A.Z. Scenario analysis of flood control structures using a multi-criteria decision-making technique in Northeast Iran. Nat. Hazards 2017, 87, 1827-1846. [CrossRef]

25. State Bureau of Technical Supervision; Ministry of Construction of the People's Republic of China. Stand for Flood Control; China Planning Press: Beijing, China, 1994; pp. 1-58.

26. Yu, J.J. Study on Flood Control Standards in Great Plain River Network Regions. J. Irrig. Drain. 2013, 32, 57-60. (In Chinese)

27. Gericke, O.J.; Plessis, J.A. Evaluation of the standard design flood method in selected basins in South Africa. J. S. Afr. Inst. Civ. Eng. 2012, 54, 2-14.

28. Byun, K.; Hamlet, A.F. A risk-based analytical framework for quantifying non-stationary flood risks and establishing infrastructure design standards in a changing environment. J. Hydrol. 2020, 584, 124575. [CrossRef]

29. Li, J.Z.; Sun, H.F.; Feng, P. How to update design floods after the construction of small reservoirs and check dams: A case study from the Daqinghe river basin, China. J. Earth Syst. Sci. 2016, 125, 795-808. [CrossRef]

30. Rosello, M.J.P.; Cantos, J.O.; Rodriguez, M.M. Review of flood risk management policies in Spain: From structural actions to spatial planning. Ciudad Territ. Estud. Territ. Cytet 2018, 50, 417-438.

31. Thaler, T.; Nordbeck, R.; Loschner, L.; Seher, W. Cooperation in flood risk management: Understanding the role of strategic planning in two Austrian policy instruments. Environ. Sci. Policy 2020, 114, 170-177. [CrossRef]

32. Nagumo, N.; Ohara, M.; Kuribayashi, D.; Sawano, H. The 2015 Flood Impact due to the Overflow and Dike Breach of Kinu River in Joso City, Japan. J. Disaster Res. 2016, 11, 1112-1127. [CrossRef]

33. Kyuka, T.; Okabe, K.; Shimizu, Y.; Yamaguchi, S.; Hasegawa, K.; Shinjo, K. Dominating factors influencing rapid meander shift and levee breaches caused by a record-breaking flood in the Otofuke River, Japan. J. Hydro-Environ. Res. 2020, 31, 76-89. [CrossRef]

34. Hsu, T.W.; Shih, D.S.; Chen, W.J. Destructive Flooding Induced by Broken Embankments along Linbian Creek, Taiwan, during Typhoon Morakot. J. Hydrol. Eng. 2015, 20, 05014025. [CrossRef]

35. Butera, I.; Climaci, M.; Tanda, M.G. Numerical analysis of phreatic levels in river embankments due to flood events. J. Hydrol. 2020, 590, 125-382. [CrossRef]

36. Amil, T.A. Determining of Different Inundated Land Use in Salyan Plan during 2010 the Kura River Flood Through GIS and Remote Sensing Tools. Int. J. Eng. Geosci. 2018, 3, 80-86. [CrossRef]

37. Thumerer, T.; Jones, A.P.; Brown, D. A GIS based coastal management system for climate change associated flood risk assessment on the east coast of England. Int. J. Geogr. Inf. Sci. 2020, 14, 265-281. [CrossRef]

38. Sattar, A.; Goswami, A.; Kulkarni, A.V. Application of 1D and 2D hydrodynamic modeling to study glacial lake outburst flood (GLOF) and its impact on a hydropower station in Central Himalaya. Nat. Hazards 2019, 97, 535-553. [CrossRef]

39. Yalcin, E. Two-dimensional hydrodynamic modelling for urban flood risk assessment using unmanned aerial vehicle imagery: A case study of Kirsehir, Turkey. J. Flood Risk Manag. 2019, 12, 12499. [CrossRef]

40. Ahmad, S.S.; Simonovic, S.P. System dynamics and hydrodynamic modelling approaches for spatial and temporal analysis of flood risk. Int. J. River Basin Manag. 2015, 13, 443-461. [CrossRef]

41. Yoo, C.; Lee, J.; Lee, M. Parameter Estimation of the Muskingum Channel Flood-Routing Model in Ungauged Channel Reaches. J. Hydrol. Eng. 2017, 22, 05017005. [CrossRef]

42. Akbari, R.; Hessami, K.M.R.; Shojaee, S. Flood Routing: Improving Outflow Using a New Non-linear Muskingum Model with Four Variable Parameters Coupled with PSO-GA Algorithm. Water Resour. Manag. 2020, 34, 3291-3316. [CrossRef]

43. Bozorg, H.O.; Abdi, D.M.; Hamedi, F.; Pazoki, M.; Loaiciga, H.A. Generalized Storage Equations for Flood Routing with Nonlinear Muskingum Models. Water Resour. Manag. 2019, 33, 2677-2691. [CrossRef]

44. Huang, J.C.; Qi, L.Y.; Gao, J.F.; Kim, D.K. Risk assessment of hazardous materials loading into four large lakes in China: A new hydrodynamic indicator based on EFDC. Ecol. Indic. 2017, 80, 23-30. [CrossRef] 
45. Jahandideh, T.M.; Helfer, F.; Zhang, H.; Jenkins, G.; Yu, Y.Y. Hydrodynamic modelling of a flood-prone tidal river using the 1D model MIKE HYDRO River: Calibration and sensitivity analysis. Environ. Mont. Assess. 2020, 192, 2. [CrossRef] [PubMed]

46. Nigussie, T.A.; Altunkaynak, A. Modeling the effect of urbanization on flood risk in Ayamama Watershed, Istanbul, Turkey, using the MIKE 21 FM model. Nat. Hazards 2019, 99, 1031-1047. [CrossRef]

47. Bhola, P.K.; Leandro, J.; Disse, M. Building hazard maps with differentiated risk perception for flood impact assessment. Nat. Hazards Earth Syst. 2020, 20, 2647-2663. [CrossRef]

48. Hossain, M.K.; Meng, Q.M. A fine-scale spatial analytics of the assessment and mapping of buildings and population at different risk levels of urban flood. Land Use Policy 2020, 99, 104829. [CrossRef]

49. Villuri, V.G.K.; Pasupuleti, S.; Jain, K.; Gairola, A.; Singh, R.K. Hydrodynamic simulation of a cloudburst event in Asi Ganga Valley of Indian Himalayan region using MIKE11 and GIS techniques. Mausam 2018, 69, 523-534. [CrossRef]

50. Ahn, J.; Na, Y.; Park, S.W. Development of Two-Dimensional Inundation Modelling Process using MIKE21 Model. KSCE J. Civ. Eng. 2019, 23, 3968-3977. [CrossRef]

51. Li, W.J.; Lin, K.R.; Zhao, T.T.G.; Lan, T.; Chen, X.H.; Du, H.W.; Chen, H.Y. Risk assessment and sensitivity analysis of flash floods in ungauged basins using coupled hydrologic and hydrodynamic models. J. Hydrol. 2019, 572, 108-120. [CrossRef]

52. Yoon, H.L.; Hyun, I.K.; Kun, Y.H.; Won, H.H. Flood Evacuation Routes Based on Spatiotemporal Inundation Risk Assessment. Water 2020, 12, 2271. [CrossRef]

53. Hawker, L.; Neal, J.; Tellman, B.; Liang, J.Y.; Schumann, G.; Doyle, C.; Sullivan, J.A.; Savage, J.; Tshimanga, R. Comparing earth observation and inundation models to map flood hazards. Environ. Res. Lett. 2020, 15, 124032. [CrossRef]

54. Arinta, R.R.; Suyoto, S.; Emanuel, A.W.R. Effectiveness of Gamification for Flood Emergency Planning in the Disaster Risk Reduction Area. Int. J. Eng. Pedagog. 2020, 10, 108-124. [CrossRef]

55. Naser, A.; Muhammad, A.A.H.; Newton, H.; Biswajeet, P. Flood risk assessment: Role of mitigation capacity in spatial flood risk mapping. Geocarto Int. 2021, 11, 1-23. [CrossRef]

56. Masaru, M. Flood Risk Impact Factor for Comparatively Evaluating the Main Causes that Contribute to Flood Risk in Urban Drainage Areas. Water 2014, 6, 253-270. [CrossRef]

57. Houston, D.; Ball, T.; Werritty, A.; Black, A.R. Social Influences on Flood Preparedness and Mitigation Measures Adopted by People Living with Flood Risk. Water 2021, 13, 2972. [CrossRef]

58. Fan, J.; Huang, G. Evaluation of flood risk management in Japan through a recent case. Sustainability 2020, 12, 5357. [CrossRef]

59. Skilodimou, H.D.; Bathrellos, G.D.; Alexakis, D.E. Flood Hazard Assessment Mapping in Burned and Urban Areas. Sustainability 2021, 13, 4455. [CrossRef]

60. Skilodimou, H.D.; Bathrellos, G.D.; Chousianitis, K.; Youssef, A.M.; Pradhan, B. Multi-hazard assessment modeling via multicriteria analysis and GIS: A case study. Environ. Earth Sci. 2019, 78, 47. [CrossRef] 